\title{
Trend of Mineral Commodity Price and its Impact on the Indonesia Economy 1990-2025
}

\author{
Ukar Wijaya Soelistijo ${ }^{1,2,3}$, Pakerti Lutzow Anjani ${ }^{4}$, Hanif Ikhsan Pratama ${ }^{4}$, Hariono La Pili ${ }^{5}$, \\ Mixsindo Korra Herdyanti ${ }^{6}$ \\ ${ }^{1}$ University of Islam Bandung (UNISBA), Department of Mining Engineering, Faculty of Engineering, Bandung, Indonesia \\ ${ }^{2}$ Institute of Technology Bandung Department of Mining Engineering, Faculty of Mining and Petroleum Engineering, Bandung, Indonesia \\ ${ }^{3}$ Center for Education and Training of Mineral and Coal, Ministry of Energy and Mineral Resources, Bandung, Indonesia \\ ${ }^{4}$ Institute of Technology Bandung, Department of Mining Engineering, Faculty of Mining and Petroleum Engineering, Bandung, Indonesia \\ ${ }^{5}$ University of Halu Oleo, Department of Mining Engineering; Faculty of Engineering, Kendari, Indonesia \\ ${ }^{6}$ University of Trisakti, Department of Mining Engineering, Faculty of Engineering, Jakarta, Indonesia
}

\section{Email address:}

ukar@tekmira.esdm.go.id (U. W. Soelistijo), tiapakerti@gmail.com (P. L. Anjani), pratama.hanifikhsan@gmail.com (H. I. Pratama), hariono.pili@gmail.com (H. L. Pili), mixsindokorra@gmail.com (M. K. Herdyanti)

\section{To cite this article:}

Ukar Wijaya Soelistijo, Pakerti Lutzow Anjani, Hanif Ikhsan Pratama, Hariono La Pili, Mixsindo Korra Herdyanti. Trend of Mineral Commodity Price and its Impact on the Indonesia Economy 1990-2025. Earth Sciences. Vol. 4, No. 4, 2015, pp. 129-145.

doi: 10.11648/j.earth.20150404.11

\begin{abstract}
Indonesia is one of the mineral rich developing countries in the world. Indonesia has a large quantity of mineral resources such as natural oil and gas, hard minerals (metallic, non metallic/industrial mineral, coal, and stone), because it is located in the Pacific ring of fire. Mineral and energy commodities have always been giving contribution to Gross Domestic Product (GDP) of Indonesia besides doing regional development, because of its potential mineral resources. Trade of mineral commodity aims is to gain from trade of mineral to increase economic growth through Balance of Trade (BOT). Mineral commodity markets have been volatile for a long time. The trends of mineral commodity prices have been fluctuated and recently it changed dramatically due to commodity prices to increase within only several years. The aims of this study are to comprehend recent contribution of mining sector to Indonesian economy 1990-2014 and to analyze forecasting of mineral commodity future prices until 2025. The price trends of commodity mineral is increasing from time to time, but sometimes decreasing because of world crisis, scarcity, and other problems in the world related to mining, trade, and relationship between countries, such as fundamentals matter, including long-run demand growth, technical change that opens up new sources of supply, changes that transform the operation of financial markets, and macro-economic shocks, etc. Mining sector contribute about 6-12\% of Indonesian Gross Domestic Product and increasing from time to time. Contribution of mining includes trade of mineral commodity, regional development by companies, etc. It is shown that mining is important for Indonesian economy. Methodology applied in this paper is data analysis using dynamic commodity and macroeconomic models and forecast using linear and polynomial regression with its trend line.
\end{abstract}

Keywords: Mineral, Price Trend, Trade, Forecast, Economy

\section{Introduction}

Indonesia has high economy potency and began to be considered internationally. The high economy potency is shown by the growth of Gross Domestic Product (GDP) which is increasing from 2000 until 2014 besides doing regional development [30]. It is still expected that it would be going on beyond the year of 2015 and on. It makes foreign investors interested to invest the capital in Indonesia [42].
Even mineral resources utilization has been well carried out since the early of 1970s. The strong macroeconomic growth and the increasing in foreign investment are caused by some reasons, those are: natural resources (variety and the great number of commodity), great population of young generation, stability of political (relative), the wise fiscal management by end of 1990 s, the strategic location to the economic giants, China and India and also the low wage for employee.

From some reasons above, the concern is on natural 
resources especially in mining sector. Indonesia has many potential natural resources, because Indonesia is a part of Pacific Ring of Fire (Figure 1), a string of volcanoes and sites of seismic activity, or earthquakes, around the edges of the Pacific Ocean. It causes Indonesia has many volcanoes, so that Indonesia has variety of minerals and other natural resources. Mining sector in Indonesia is divided to three types of sub-sector, those are oil and gas mining sub-sector, general mining sub-sector (metallic and non-metallic or industrial mineral mining, coal and quarry). Presently, the biggest contribution is coming from general mining subsector. The amount of impact from mining sector to Indonesian GDP must be known as well. The forecast of price commodity especially mining sector commodity must also be known to predict the strategy for Indonesia Government to facing Indonesian future economy as well as world's economy. The forecasting will be carried out until 2025. It is known that mining sector commodities is un- renewable ones and its good management is well required. Mineral and energy (oil, gas and coal) commodities have always been giving contribution to Gross Domestic Product (GDP) of Indonesia because of its potential resources. Mining is an important sector in Indonesian economy. This sector is a prime source of GDP which gains profit to national income through trade of its commodity [31-33,3641]. Mining sector contributes about $6.72-12.07 \%$ of Indonesian GDP in 2000-2014 (BPS, 2014 [15]).Mineral trade policy experienced periods of Indonesia has high economy potency and began to be considered internationally. The high economy potency is shown by the growth of Gross Domestic Product (GDP) which is increasing from 2000 until 2014. It is still expected that it would be going on beyond the year of 2015 and on. It makes foreign investors interested to invest the capital in Indonesia [42], as done by the year of 1997 as the year of Indonesia economic crisis happened.

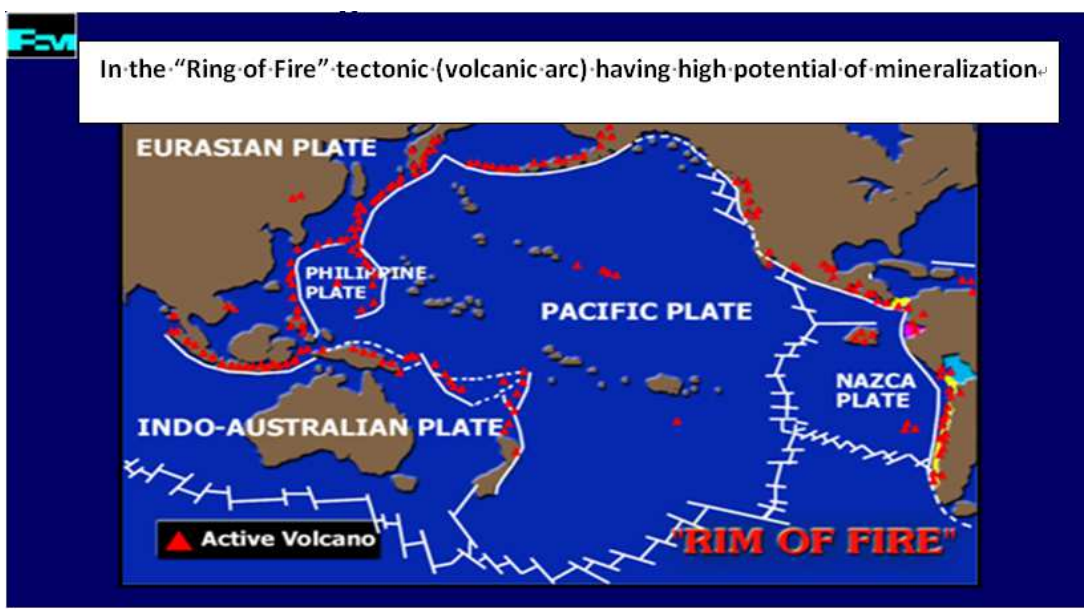

Sources: PT Freeport Indonesia-Freeport Mac Moran, 2013; http://en.wikipedia.org/wiki/Ring_of_Fire [13] (edited)

Figure 1. Pacific Ring of Fire.

Trade of mineral commodity aims for gains from trade of mineral to increase economic growth through Balance of Trade (BOT). BOT is the difference between the monetary value of exports and imports of output in an economy over a certain period, measured in the currency of that economy. The trade balance is identical to the difference between a country's output and its domestic demand. The difference between what goods a country produces and how many goods it buys from abroad; this does not include money re-spent on foreign stock, nor does it factor in the concept of importing goods to produce for the domestic market (Wikipedia [14]).Mineral commodity markets have been volatile for a long time. The trends of mineral commodity prices have been fluctuated and recently it changed dramatically cause commodity prices to multiply within only several years. These price fluctuations strongly affect the world economy and affected by scarcity of these minerals. Indonesia cannot be secluded from countries in the world whose economy is affected from mining of these mineral commodities. Mining in Indonesia is conducted by government (state-owned companies) and private companies. These companies try to understand the risk of mineral economics especially price trends in order to facilitate the feasibility of long term mine planning. To predict the risk of entire economies depending on mineral commodities, forecasting is essential. Forecasting mineral commodity price trends requires time series data of historical mineral commodity price trends. The aims of this study are to comprehend recent contribution of mining sector to Indonesian economy 1990-2014 and to analyze forecasting of mineral commodity future prices until 2025 and also to analyze effect of mineral commodity price trends to the Indonesian economy. The key questions tackled(i) how is mineral commodity price trends forecast up to 2025? and (ii) how big the impact of mining on Indonesian economy? Methodology applied in this paper are data analysis using dynamic commodity as well as macroeconomic models and forecast using linear and polynomial regression with its trend line.

\section{Materials and Methods}

Dynamic Commodity and Macroeconomic Models. The main points of the dynamic commodity model may include: 
(1) Calculation of the amount required to reserve.

a. Approach through the quantity of the commodity.

b. Approach through commodity prices.

(2) Calculation of benefit and loss.

a. Data input.

b. Output each year.

Formula to model the dynamic commodity among others (Labys, 1973; Soelistijo, 1991, 201; Schaeffer, 2008 [24; 34, 35; 29]):

Demand for commodity: D = d (D-1, PW, PS, A, TF)

This relationship can be explained that the requirement (D) depends on endogenous variables changed, needs of the past (D-1), the international price (PW), the level or the level of economic activity (A), prices of one or more commodities direction substitute (PS), and the possibility technical effect (TF) as well as the growth of synthetic substitutes.

Supply of commodity: Q = q (Q-1, PW-1, U, NR, Z)

Supply (Q) will depend on the prices of the past (PW-1), the amount of reserves $(\mathrm{U})$, natural resources $(\mathrm{NR})$, and the possibility of change of policy (Z). Future price changes past included because the supply of goods usually depend on past factors which is generally translated as price.

Commodity prices: $\mathrm{P}=\mathrm{p}(\mathrm{P}-1, \mathrm{D}, \mathrm{I})$

Price $(\mathrm{P})$ will depend on price changes of the past (P-1), needs (D), and stock (IC). While the amount of stock is the stock of the past (IC-1) plus the provision of demand and present stock of commodity (IC).

Stock commodity: IC = IC-1 + Q - D

Besides gained added relationship supply demand:

Relationship of supply-demand: $\mathrm{C}=\mathrm{Q}+\mathrm{M}-\mathrm{X}+(-) \mathrm{S}$

Where the stock as the use of $(\mathrm{C})$ is the provision plus imports (M) reduced export (E).

Macroeconomic model applied in this study may cover the Gross Domestic Product (GDP) from the expenditure side(Ye)[38,41,45]:

$$
\mathrm{Ye}=\mathrm{C}+\mathrm{I}+\mathrm{G}+\mathrm{X}-\mathrm{M}
$$

where $\mathrm{C}=$ consumption, $\mathrm{I}=$ investment, $\mathrm{G}=$ government spending, $\mathrm{X}=$ exports and $\mathrm{M}=$ imports. In this case $(\mathrm{X}-\mathrm{M})$ is also called Balance of Trade (BOT) that will be observed within 2000-2014 and its projection in 2015-2025 due to the impact of the mineral commodity price trend. In general it could be formulated as $\mathrm{Ye}=\mathrm{f}(\mathrm{I}, \mathrm{C}, \mathrm{G}, \mathrm{BOT})$.

From the income side PDB (Yi) :

$$
\mathrm{Yi}=\mathrm{f}(\mathrm{K}, \mathrm{L}, \mathrm{R}, \mathrm{I}, \mathrm{E}, \mathrm{Z})_{\mathrm{T}},
$$

where $\mathrm{K}=$ capital, $\mathrm{L}=$ labor, $\mathrm{R}=$ natural resources, $\mathrm{I}=$ information, $\mathrm{E}=$ environmental cost, $\mathrm{T}=$ technology, $\mathrm{Z}=$ other variables. In this study mining sector may be included in the sector of natural resources.

Forecasting. Forecasting is the process of making statements about events whose actual outcomes (typically) have not yet been observed. A commonplace example might be estimation of some variables of interest at some specified future date. Prediction is a similar, but more general term. Both might refer to formal statistical methods employing time series, cross-sectional or longitudinal data, or alternatively to less formal judgmental methods. Usage can differ between areas of application: for example, in hydrology, the terms "forecast" and "forecasting" are sometimes reserved for estimates of values at certain specific future times, while the term "prediction" is used for more general estimates, such as the number of times floods will occur over a long period. Risk and uncertainty are central to forecasting and prediction; it is generally considered good practice to indicate the degree of uncertainty attaching to forecasts. In any case, the data must be up to date in order for the forecast to be as accurate as possible.

Time series analysis comprises methods for analyzing time series data in order to extract meaningful statistics and other characteristics of the data. Time series forecasting is the use of a model to predict future values based on previously observed values. While regression analysis is often employed in such a way as to test theories that the current values of one or more independent time series affect the current value of another time series, this type of analysis of time series is not called "time series analysis", which focuses on comparing values of a single time series or multiple dependent time series at different points in time.

Exponential smoothing is a technique that can be applied to time series data, either to produce smoothed data for presentation, or to make forecasts. The time series data themselves are a sequence of observations. The observed phenomenon may be an essentially random process, or it may be an orderly, but noisy, process. Whereas in the simple moving average the past observations are weighted equally, exponential smoothing assigns exponentially decreasing weights over time.

The raw data sequence is often represented by beginning (X)at time $\mathrm{t}=0$, and the output of the exponential smoothing algorithm is commonly written as $\mathrm{S}_{t}$, which may be regarded as a best estimate of what the next value of will be.

$$
\begin{aligned}
& s_{t}=\alpha x_{t}+(1-\alpha) s_{t-1}, t>0 \\
& \text { where } \alpha \text { is the smoothing factor, and } 0<\alpha<1 \text {. }
\end{aligned}
$$

Linear regression is an approach for modeling the relationship between a scalar dependent variable y and one or more explanatory variables (or independent variable) denoted $\mathrm{X}$. In linear regression, data are modeled using linear predictor functions, and unknown model parameters are estimated from the data. Linear regression was the first type of regression analysis to be studied rigorously, and to be used extensively in practical applications. A linear regression line has an equation of the form $\mathrm{Y}=\mathrm{a}+\mathrm{b} \mathrm{X}$, where $\mathrm{X}$ is the explanatory variable and $\mathrm{Y}$ is the dependent variable. The slope of the line is $b$, and $a$ is the intercept (the value of $y$ when $\mathrm{x}=0$ ).

Polynomial regression is a form of linear regression in which the relationship between the independent variable $\mathrm{x}$ and the dependent variable $\mathrm{y}$ is modeled as an nth degree polynomial. Polynomial regression fits a nonlinear 
relationship between the value of $\mathrm{x}$ and the corresponding conditional mean of $\mathrm{y}$, denoted $\mathrm{E}(\mathrm{y} \mid \mathrm{x})$. The goal of regression analysis is to model the expected value of a dependent variable $y$ in terms of the value of an independent variable (or vector of independent variables) $x$. The polynomial regression model:

$$
y_{i}=a_{0}+a_{1} x_{i}+a_{2} x_{i}^{2}+\cdots+a_{m} x_{i}^{m}+\varepsilon_{i}(i=1,2, \ldots, n)
$$

Trend line represents a trend, the long-term movement in time series data after other components have been accounted for. It tells whether a particular data set (say GDP, oil prices or stock prices) have increased or decreased over the period of time. A trend line could simply be drawn by eye through a set of data points, but more properly their position and slope is calculated using statistical techniques like linear regression. Trend lines typically are straight lines, although some variations use higher degree polynomials depending on the degree of curvature desired in the line [Gujarati, 2006 [21]; Maddala, 1977 [ 26].

Data. National income calculation is using the Gross Domestic Product (GDP) in 2000 up to 2014 as a reference of national income. The data consists of the GDP of Mining Sector, Total GDP, and General Mineral Sector contribution as shown in Table 1[1-17].

Balance of trade (BOT) calculation is using the BOT in 1984 up to 2014. The data consists of Total Export, Total Import, Total Surplus/deficit (BOT), Oil and Gas Surplus/deficit (BOT), and Non Oil and Gas Surplus/deficit(BOT) as shown in Table 2 [15].

Actual price of mineral commodity based on its own units per year in 1990 up to 2014. Data sources are LME, World Bank and OPEC (Table 3) [1-14, 16-18].

\section{Results and Discussion}

Price Trends of Mineral Commodity, 1990-2014. The actual price trends of mineral commodity from 1990 to 2014 based on their own units in trade is shown in Figure 2 [1-18].

The prices of several important mineral commodities, including fossil fuels and metals, have repeatedly undergone periods of boom and bust over the last 150 years (Cuddington et al, 2008; Jacks et al., 2011 [19, 23]). These long-term fluctuations affect the macroeconomic conditions of developing and industrialized countries (World Trade Organization, 2010; IMF, 2012 [46]), one of these countries is Indonesia. Commodity price fluctuations have a big impact on Indonesian economy conditions, especially energy commodity such as oil, gas, and coal. Broad-based commodity price declines occurred in the second half of 2014 (World Bank, 2015 [46]). Crude oil prices declined the most, down from $\$ 104.08 /$ TOE in 2013 to $\$ 96.24 /$ TOE in 2014 , bringing an end to a four-year period of high and stable prices. The weakness in crude oil prices will extend to other energy markets, especially natural gas in Europe and Asia.

Revisions of supply and demand expectations have played a key role during the course of the current episode of declining oil prices, such revisions are neither unique nor unusually large; what is unique is that these changing expectations unfolded together with a number of other key developments: change in
OPEC's objectives, receding geopolitical risks, and U.S. dollar appreciation. Together, these forces have formed a "perfect storm" of conditions that are exerting strong downward pressure on prices (World Bank, 2015 [46]). Price of metals are also falling down recently, for some metals such as iron ore, copper, lead, and tin prices all fell in 2014. However, Indonesia's export ban on unprocessed ore affected the nickel market in particular, so the price of nickel strengthened in 2014.Table4shows the forecast of price trends of mineral commodity and the formula. Figures 3 and 4 shows the price trend of mineral commodities based its actual price and price indices respectfully and figure 4 shows oil versus gold price that affected each other.

It could also be shown on the tables and the graphs, that all mineral commodities (metal, oil, gas, and coal) have the same increasing pattern from 1990 to 2008 (peak point) but in 2009, all mineral price was decreasing because of the world crisis caused by America. This world crisis not only affected mining commodity but also all commodities in trade. After 2009 the trend was increasing, but in 2012 decreased especially for coal because China stopped importing coal from their country. No other country has the same power to import coal as big as China, so when it happened it affected all coal exporting countries.

Gross Domestic Product of Indonesia, 2000-2014.Gross Domestic Product (GDP) of Indonesia from 2000 to 2014 could be seen on Table 1in constant billion IDR of 2000 base price (Badan Pusat Statistik Indonesia 2015,,[15]). The graph consists of GDP of Indonesia, general mining (and industrial mineral) sector, and its subsector. It can be seen that from the graph how much mining sector contribution to Indonesian GDP. Indonesian GDP increases from time to time until 2014 so the economic growth is positive of around $6 \%$ per year. In IDR current value the GDP trend is shown in Figure 7.

Balance of Trade of Indonesia, 2000-2014.BOT of Indonesia could be seen on Figure 8 shown in current US\$, consisted of total export, total import, oil and gas surplus/deficit (BOT),non oil and gas surplus/deficit (BOT), and total surplus/deficit (BOT). It can be seen from the graph that export and import trend is increasing, but it doesn't happen to oil and gas surplus/deficit (BOT) because it is decreasing. Although the oil and gas surplus/deficit (BOT) is decreasing, non oil and gas surplus/deficit(BOT) balance with increasing trends. However, for the recent years non oil and gas surplus/deficit (BOT) is also decreasing, so total BOT is negative.

2000s Commodity boom. Since 2000, many prices of mineral commodity experienced increasing trend. For example, in 2000, Aluminum price is $1551,5 \mathrm{US} \$$ /ton, nickel is 8630 US\$/ton and copper is $1580 \mathrm{US \$ /ton.} \mathrm{But} \mathrm{in} \mathrm{2010,} \mathrm{the} \mathrm{price} \mathrm{of}$ Aluminum is reached to level $2148 \mathrm{US} \$ /$ ton, nickel is 21810 
US\$/ton and copper is $7538 \mathrm{US \$ /ton.} \mathrm{Each} \mathrm{price} \mathrm{of} \mathrm{them} \mathrm{have}$ been tripled or more. This phenomenon is called 2000s commodity boom.

Based on Radetzki, 2006 [27] and Sruermer, 2013 [44], the causes of this commodity boom is because of increasing demand that ignited by the next three reasons. Firstly, the fast economic growth in OECD countries. OECD or The Organization for Economic Co-operation and Development (OECD) is an international economic organization of 34 countries founded in 1961 to stimulate economic progress and world trade. The member of this organization is mostly countries in Europe, North America, Australia and some from South America. The economic growth is reported 3.3\% GDP growth per year. This fast growth increases the demand of mineral commodity. Secondly, the explosive growth of China and India raw material demand. Especially for China, in 20002005 , China share in global demand of oil is $28 \%$, aluminum is $50 \%$, steel is $84 \%$ and copper is $95 \%$. This is a very strong demand from China to support the development in its country and causes major increase in global demand. Third reason is, the speculative activity due to negative stock market. The speculative activity could also increase the price of commodity.

The increase of the commodity demand is failed to be answered by the supply from the mining industry and causes the prices to increase. Radetzki (2008) [28], briefly give explanation to this condition by two reasons. Firstly, high demand of mineral commodity is not accompanied by supply because of long installation time to build new supply system. The average time is 5 years, but the demand is need to be fulfilled immediately. Secondly, the investors failed to understand the needed capacity of the current demand. This makes the investment in building new supply system is low. Thirdly, the cost of finding and developing new mineral deposit are rising. According to the increasing price of mineral commodity, the price of exploration had been influenced too as the price of mineral commodity will drive the price of other goods and equipments needed for exploration activity, increased too.

Contribution of Mining Sector to Indonesia GDP. Mineral commodities (oil and gas, hard minerals and coal) is a major contributor to GDP Indonesia, despite its declining trend but the percentage is increasing its value (Figure 2).Since 2009 the percentage of GDP from hard mineral and coal exceed the GDP contribution of oil and gas, this is due to the volume of oil lifting Indonesia continues to decline and a stronger price mineral commodities on the world market, in addition to the huge demand of the commodity minerals from China such as iron, nickel, bauxite and others led to the phenomenon of large-scale production at several mineral commodities (nickel and bauxite) and made Indonesia as the largest exporter of several mineral commodities. This condition directly affects to the increased contribution of tax and non-tax revenues and increase the value of the mineral and coal sector's contribution to Indonesia GDP.

Law No. 4 on Mineral and Coal Mining was issued in 2009 replacing the previous Law No. 11 In 1967, one of its mandate is the mandatory of the mining company to commence added value process to mineral commodity such as refining process, as the implementation of the MER (Mineral and Energy Resources) Ministerial Decree No. 7/2012 that restrict the export of raw material with a certain quota, and implementation of export tax to metallic mineral export. This condition results metallic mineral export volume dropped dramatically at the beginning of the policy implementation, but the volume of exports minerals back to increase until the end of the beginning of 2014, where the government re-issued Government Regulation No. 1/2014 and MER Ministerial Decree No. 1 of 2014 which prohibits the export of almost all metallic minerals, with the exception of copper, iron (iron sand and iron ore) with a certain level of concentrate restrictions and customs duties export progressively from $20 \%$ in the first year to $60 \%$ in the year 2016 .

Mineral commodity forecasting to 2025.Forecasting is the art and science of predicting events that will occur with the use of historical data and project it into the future with some form of mathematical models. Based on the results of the commodity price forecasting oil and gas, minerals and coal showed that from year to year the commodity will increase the price. This suggests that there will be progressive increase of the demand of the commodity. The results of this commodity price projection can assist in preparing Indonesian government to compete with the global market that will be faced in 2025 .

Mineral commodity prices have a significant influence on the production and adjustment of industrial structure of the mineral. International mineral market is influenced by many factors, it is very difficult to discern mechanism of factors forming the price of the mineral. All of this led to the mineral market investments that have uncertainty, uncertainty is seen in the difficulty to predict the price of minerals, so it's important for us to do with the price forecasting methods and the corresponding theory (Yong Li, 2012 [25]).

Forecasting of mineral commodity price is done using statistic regression, whether it is linear, exponential or polynomial. The selection of the regression is based on the coefficient of correlation or $\mathrm{R}^{2}$ of the equation. The equation is come from analysis of trend of the price using historical time series from 1990 to 2014. By using the equation, forecasting of mineral commodity price is as following table.

Based on the forecasting formula of each commodity, the forecast price until 2025 is then plotted as graph in Figure 3. It can be shown that all the commodity is predicted to experience a major increasing. This correlates with previous increasing trend of price from 1990-2014. The behavior of the mineral commodity price could be discussed in point of view per commodity as follows.

Petroleum (Oil, LPG and LNG). Petroleum has been dominating the primary energy supply in Indonesia, with a share of about $37 \%$. Considering the price of oil tends to increase whereas oil reserves and production of domestic crude oil continues to decline, the government has to establish policies to reduce dependence on oil supply through energy diversification programs. Petroleum prices continue to rise beyond US\$100, though now it is not dominated by 
OPEC, but the political situation of the countries in middle east influences on world oil prices

Based on Table 4 and Figure 3 obtained prediction of oil price in 2025 of US\$251.42 per TOE. Natural gas (LPG and LNG) is currently the third major primary energy source in Indonesia, after petroleum and coal, with a share of about $15 \%$. Gas supply comes from the oil and gas field in the country. In the past period, the majority of natural gas production largely utilized for export in the form of LNG and gas pipelines. With the ever increasing domestic energy demand, while prices oil is likely to increase the demand for natural gas also is estimated to continue increase. Based on Table 4 and Figure 3 obtained prediction of LPG and LNG price in 2025 of US\$ 6.99 and US\$ 6.89 per MBTU.

Table 1. Gross Domestic Product of Indonesia 2000-2014(In Constant Billion IDR Year 2000).

\begin{tabular}{|c|c|c|c|c|c|c|c|}
\hline \multirow[b]{2}{*}{ Year } & \multirow[b]{2}{*}{ Mining Sector } & \multicolumn{3}{|c|}{ Mining Sector } & \multirow[b]{2}{*}{ GDP Total } & \multirow[b]{2}{*}{$\begin{array}{l}\text { GDP of Non Oil } \\
\text { and Gas }\end{array}$} & \multirow[b]{2}{*}{$\begin{array}{l}\text { Mining Sector } \\
\text { Contribution (\%) }\end{array}$} \\
\hline & & $\begin{array}{l}\text { Oil and Gas } \\
\text { Mining }\end{array}$ & $\begin{array}{l}\text { Metallic Mineral } \\
\text { Mining }\end{array}$ & $\begin{array}{l}\text { Industrial } \\
\text { Mineral } \\
\end{array}$ & & & \\
\hline 2000 & $167,692.20$ & $117,156.00$ & $38,990.30$ & $11,545.90$ & $1,389,769.90$ & $1,218,334.10$ & $12.07 \%$ \\
\hline 2001 & $168,244.40$ & $111,450.90$ & $44,720.30$ & $12,073.20$ & $1,440,405.70$ & $1,278,060.00$ & $11.68 \%$ \\
\hline 2002 & $169,932.00$ & $108,130.60$ & $49,066.50$ & $12,734.90$ & $1,505,216.40$ & $1,344,906.30$ & $11.29 \%$ \\
\hline 2003 & $167,603.80$ & $103,087.20$ & $51,007.30$ & $13,509.30$ & $1,577,171.30$ & $1,421,474.80$ & $10.63 \%$ \\
\hline 2004 & $160,100.50$ & $98,636.30$ & $46,947.10$ & $14,517.10$ & $1,656,516.80$ & $1,506,296.60$ & $9.66 \%$ \\
\hline 2006 & $168,031.70$ & $95,853.10$ & $55,242.40$ & $16,936.20$ & $1,847,126.70$ & $1,703,422.40$ & $9.10 \%$ \\
\hline 2007 & $171,278.40$ & $94,746.60$ & $58,151.30$ & $18,380.50$ & $1,964,327.30$ & $1,821,757.70$ & $8.72 \%$ \\
\hline 2008 & $172,496.30$ & $95,167.50$ & $57,568.90$ & $19,759.90$ & $2,082,456.10$ & $1,939,625.90$ & $8.28 \%$ \\
\hline 2009 & $180,200.50$ & $95,230.00$ & $63,820.10$ & $21,150.40$ & $2,178,850.40$ & $2,036,685.50$ & $8.27 \%$ \\
\hline 2010 & $187,152.50$ & $96,146.00$ & $68,481.50$ & $22,525.00$ & $2,314,458.80$ & $2,171,113.50$ & $8.09 \%$ \\
\hline 2011 & $190,143.20$ & $95,155.20$ & $70,814.40$ & $24,173.60$ & $2,464,566.10$ & $2,322,653.10$ & $7.72 \%$ \\
\hline 2012 & $193,139.20$ & $91,691.10$ & $75,473.00$ & $25,975.10$ & $2,618,932.00$ & $2,481,790.30$ & $7.37 \%$ \\
\hline 2014 & $195,425.00$ & $86,477.60$ & $79,620.10$ & $29,327.30$ & $2,909,181.50$ & $2,779,064.00$ & $6.72 \%$ \\
\hline
\end{tabular}

Source: Badan Pusat Statistik Indonesia (BPS), 2015. [15]

Table 2. Indonesia Balance of Trade 1984-2014(US\$ million).

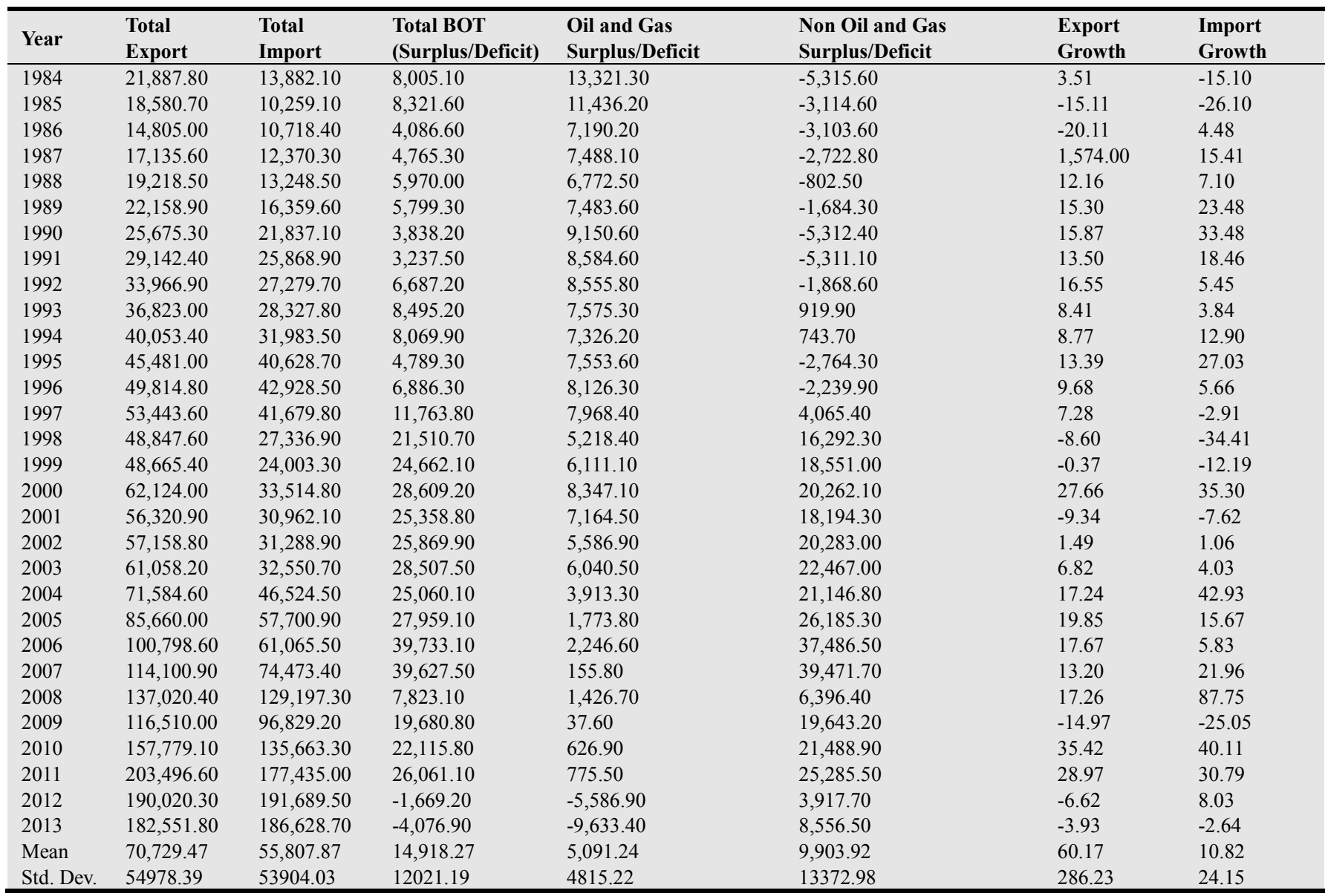

Source: Badan Pusat Statistik,processed by Trade Data and Information Center, Ministry of Trade, 2014 [15]. 
Table 3. Actual Price Trends of Mineral Commodity $1990-2014$ (\$=US\$).

\begin{tabular}{|c|c|c|c|c|c|c|c|}
\hline Year & Oil & LPG & LNG & Coal (High Rank) & Coal (Low Rank) & Gold (Au) & Silver (Ag) \\
\hline Year & (\$/TOE) & (\$/MBtu) & (\$/MBtu) & (\$/ton) & (\$/ton) & (\$/tr oz) & $(\$ /$ tr oz) \\
\hline 1990 & 22.88 & & 3.64 & 43.48 & & 383.47 & 4.83 \\
\hline 1991 & 19.37 & & 3.99 & 42.80 & & 362.18 & 4.05 \\
\hline 1992 & 19.02 & & 3.62 & 38.53 & & 343.73 & 3.95 \\
\hline 1993 & 16.84 & & 3.52 & 33.68 & & 359.77 & 4.31 \\
\hline 1994 & 15.89 & 0.78 & 3.18 & 37.18 & & 384.01 & 5.28 \\
\hline 1995 & 17.18 & 0.77 & 3.46 & 44.50 & & 384.16 & 5.20 \\
\hline 1996 & 20.42 & 0.89 & 3.66 & 38.07 & & 387.70 & 5.20 \\
\hline 1997 & 19.17 & 0.88 & 3.91 & 35.10 & & 331.10 & 4.91 \\
\hline 1998 & 13.06 & 0.77 & 3.05 & 29.23 & & 294.16 & 5.55 \\
\hline 1999 & 18.07 & 0.78 & 3.14 & 25.89 & 19.93 & 278.77 & 5.22 \\
\hline 2000 & 28.23 & 1.05 & 2.30 & 26.25 & 21.65 & 279.03 & 4.95 \\
\hline 2001 & 24.35 & 1.09 & 4.20 & 32.31 & 21.71 & 270.99 & 4.38 \\
\hline 2002 & 24.93 & 1.03 & 1.07 & 27.06 & 21.25 & 309.97 & 4.60 \\
\hline 2003 & 28.90 & 1.25 & 1.27 & 27.95 & 20.17 & 363.51 & 4.88 \\
\hline 2004 & 37.73 & 1.51 & 1.51 & 56.73 & 23.75 & 409.21 & 6.66 \\
\hline 2005 & 53.39 & 1.86 & 1.94 & 51.02 & 28.61 & 444.84 & 7.31 \\
\hline 2006 & 64.29 & 2.19 & 2.09 & 52.60 & 28.38 & 604.34 & 11.56 \\
\hline 2007 & 71.12 & 2.63 & 2.88 & 70.43 & 30.40 & 696.72 & 13.39 \\
\hline 2008 & 96.99 & 3.34 & 2.90 & 136.18 & 44.31 & 871.71 & 15.00 \\
\hline 2009 & 61.76 & 2.20 & 2.33 & 77.03 & 38.30 & 972.97 & 14.64 \\
\hline 2010 & 79.04 & 3.05 & 3.19 & 106.03 & 47.70 & $1,224.66$ & 20.15 \\
\hline 2011 & 104.01 & 3.68 & 3.66 & 129.59 & 61.05 & $1,569.21$ & 35.22 \\
\hline 2012 & 105.01 & 1.48 & 3.28 & 94.44 & 47.08 & $1,669.52$ & 31.14 \\
\hline 2013 & 104.08 & 2.58 & 3.47 & 89.02 & 44.87 & $1,411.46$ & 23.85 \\
\hline 2014 & 96.24 & 2.03 & 3.37 & 77.86 & 40.16 & $1,265.58$ & 19.07 \\
\hline
\end{tabular}

Table 3. Actual Price Trends of Mineral Commodity 1990 -2014. (Continued).

\begin{tabular}{|c|c|c|c|c|c|c|}
\hline \multirow{2}{*}{ Year } & Aluminum (Al) & Tin (Sn) & Lead $(\mathrm{Pb})$ & Copper (Cu) & Zinc (Zn) & Nickel (Ni) \\
\hline & (\$/ton) & (\$/ton) & (\$/ton) & (\$/ton) & (\$/ton) & (\$/ton) \\
\hline 1990 & $1,639.45$ & $6,085.38$ & 810.54 & $2,661.48$ & $1,513.46$ & $8,864.10$ \\
\hline 1991 & $1,302.19$ & $5,595.04$ & 557.62 & $2,338.78$ & $1,116.99$ & $8,155.62$ \\
\hline 1992 & $1,254.28$ & $6,101.03$ & 541.37 & $2,281.16$ & $1,239.78$ & $7,001.23$ \\
\hline 1993 & $1,139.05$ & $5,161.14$ & 406.36 & $1,913.08$ & 961.98 & $5,293.42$ \\
\hline 1994 & $1,476.78$ & $5,463.85$ & 547.77 & $2,307.42$ & 997.73 & $6,339.82$ \\
\hline 1995 & $1,805.66$ & $6,213.81$ & 630.95 & $2,935.61$ & $1,031.12$ & $8,228.04$ \\
\hline 1996 & $1,505.66$ & $6,165.08$ & 774.33 & $2,294.86$ & $1,025.14$ & $7,500.82$ \\
\hline 1997 & $1,599.33$ & $5,646.77$ & 624.18 & $2,276.77$ & $1,316.13$ & $6,927.39$ \\
\hline 1998 & $1,357.47$ & $5,540.33$ & 528.64 & $1,654.06$ & $1,024.47$ & $4,629.52$ \\
\hline 1999 & $1,361.09$ & $5,403.62$ & 502.62 & $1,572.86$ & $1,076.34$ & $6,011.23$ \\
\hline 2000 & $1,549.14$ & $5,435.71$ & 453.94 & $1,813.47$ & $1,128.13$ & $8,637.74$ \\
\hline 2001 & $1,443.63$ & $4,484.44$ & 476.16 & $1,578.29$ & 885.77 & $5,944.73$ \\
\hline 2002 & $1,349.92$ & $4,060.50$ & 452.68 & $1,559.48$ & 778.75 & $6,771.75$ \\
\hline 2003 & $1,431.29$ & $4,894.90$ & 515.03 & $1,779.14$ & 827.70 & $9,629.47$ \\
\hline 2004 & $1,715.54$ & $8,512.73$ & 886.55 & $2,865.88$ & $1,047.75$ & $13,823.24$ \\
\hline 2005 & $1,898.31$ & $7,379.83$ & 976.37 & $3,678.88$ & $1,381.31$ & $14,743.96$ \\
\hline 2006 & $2,569.90$ & $8,780.83$ & $1,289.72$ & $6,722.13$ & $3,275.29$ & $24,254.41$ \\
\hline 2007 & $2,638.18$ & $14,536.83$ & $2,579.99$ & $7,118.23$ & $3,242.36$ & $37,229.81$ \\
\hline 2008 & $2,572.79$ & $18,510.09$ & $2,090.66$ & $6,955.88$ & $1,874.71$ & $21,110.64$ \\
\hline 2009 & $1,664.83$ & $13,573.88$ & $1,719.27$ & $5,149.74$ & $1,655.11$ & $14,654.63$ \\
\hline 2010 & $2,173.12$ & $20,405.62$ & $2,148.45$ & $7,534.78$ & $2,160.74$ & $21,808.85$ \\
\hline 2011 & $2,401.39$ & $26,053.68$ & $2,400.81$ & $8,828.19$ & $2,193.90$ & $22,910.36$ \\
\hline 2012 & $2,023.28$ & $21,125.99$ & $2,064.64$ & $7,962.35$ & $1,950.41$ & $17,547.55$ \\
\hline 2013 & $1,846.67$ & $22,282.80$ & $2,139.79$ & $7,332.10$ & $1,910.26$ & $15,031.80$ \\
\hline 2014 & $1,867.42$ & $21,898.87$ & $2,095.46$ & $6,863.40$ & $2,160.97$ & $16,893.38$ \\
\hline
\end{tabular}

Source: LME,2015; World Bank, 2015; HBA, 2015; and OPEC, 2015[1, 7-11] 


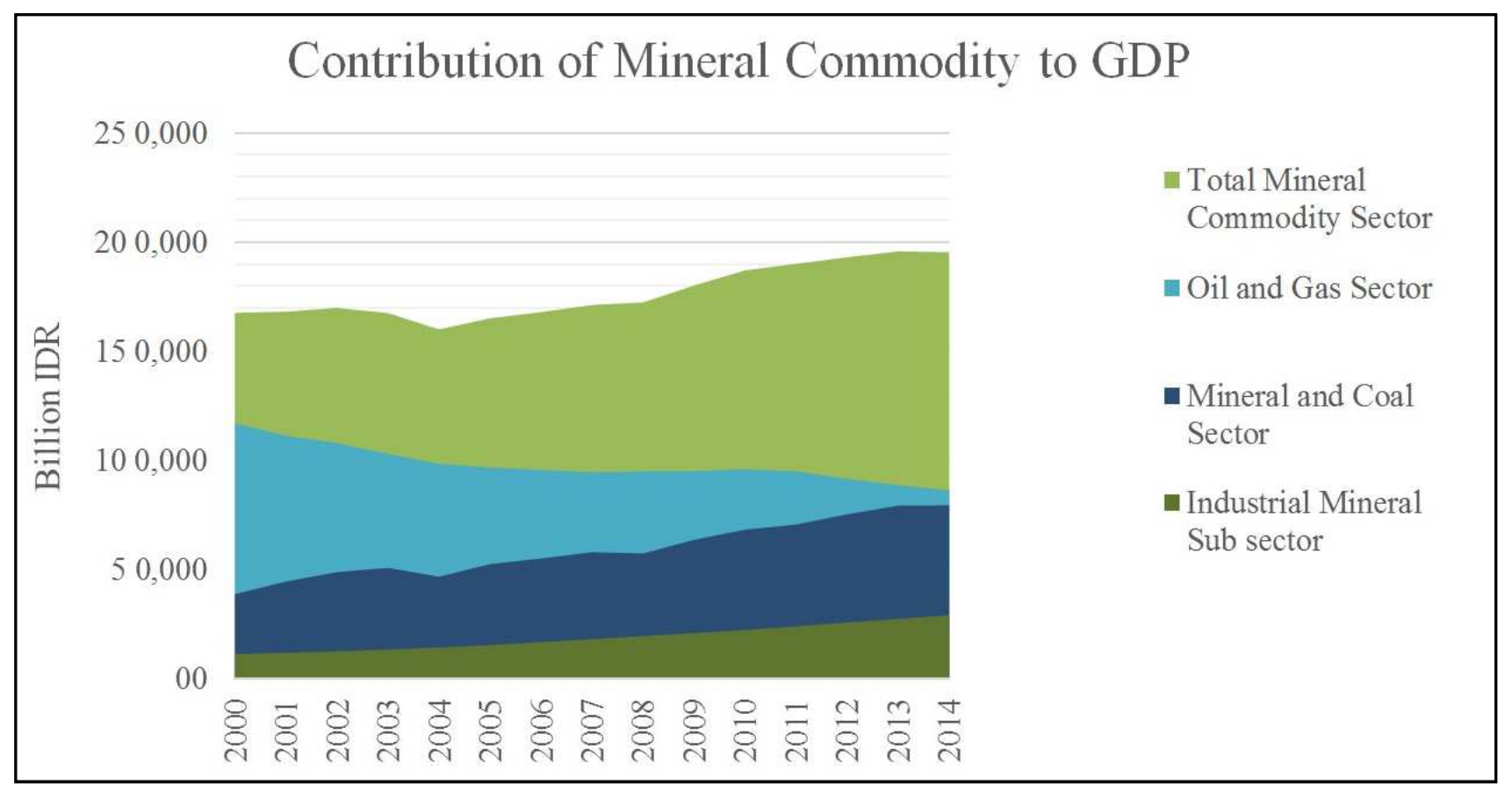

Figure 2. Contribution of Mining Sector to Indonesia GDP (2000 constant IDR CPI (consumer price index)).

Table 4. Forecast of Mineral Commodity Price Trends.

\begin{tabular}{|c|c|c|c|c|c|c|c|c|c|}
\hline \multirow{3}{*}{ NO } & \multirow{3}{*}{ COMMODITY } & \multirow{3}{*}{ UNIT } & \multirow{3}{*}{ FORECASTING FORMULA (y) } & \multirow{3}{*}{$\mathbf{R}^{2}$} & \multicolumn{5}{|l|}{ YEAR } \\
\hline & & & & & 2015 & 2016 & 2017 & 2018 & 2019 \\
\hline & & & & & 26 & 27 & 28 & 29 & 30 \\
\hline 1 & Oil & $\$ /$ TOE & $0.232 x^{2}-1.933 x+20.34$ & 0.912 & 127 & 137 & 148 & 159 & 171 \\
\hline 2 & LPG & $\$ /$ MBtu & $0.487 \mathrm{e}^{0.074 \mathrm{x}}$ & 0.746 & 3 & 4 & 4 & 4 & 4 \\
\hline 3 & LNG & $\$ / M B t u$ & $0.010 x^{2}-0.296 x+4.584$ & 0.386 & 4 & 4 & 4 & 4 & 5 \\
\hline 4 & Coal (High Rank) & $\$ /$ ton & $0.23 x^{2}-2.815 x+42.69$ & 0.63 & 125 & 134 & 144 & 154 & 165 \\
\hline 5 & Coal (Low Rank) & $\$ /$ ton & $-0.021 x^{2}+3.053 x-12.58$ & 0.742 & 53 & 55 & 56 & 58 & 60 \\
\hline 6 & Gold $(\mathrm{Au})$ & $\$ / \operatorname{troz}$ & $4.627 x^{2}-71.117 x+536.86$ & 0.8929 & 1,816 & 1,990 & 2,173 & 2,366 & 2,568 \\
\hline 7 & Silver (Ag) & $\$ /$ tr oz & $0.0736 x^{2}-0.9446 x+6.6288$ & 0.7911 & 32 & 35 & 38 & 41 & 45 \\
\hline 8 & Aluminum $(\mathrm{Al})$ & $\$ /$ ton & $1270 \mathrm{e}^{0.0222 \mathrm{x}}$ & 0.4723 & 2,262 & 2,313 & 2,365 & 2,418 & 2,472 \\
\hline 9 & $\operatorname{Tin}(\mathrm{Sn})$ & $\$ /$ ton & $789.72 x+106.11$ & 0.6810 & 20,639 & 21,429 & 22,218 & 23,008 & 23,798 \\
\hline 10 & Lead $(\mathrm{Pb})$ & $\$ /$ ton & $5.303 x^{2}-53.67 x+654.2$ & 0.783 & 2,844 & 3,071 & 3,309 & 3,558 & 3,817 \\
\hline 11 & Copper $(\mathrm{Cu})$ & $\$ /$ ton & $19.224 x^{2}-220.76 x+2620.5$ & 0.7863 & 9,876 & 10,674 & 11,511 & 12,386 & 13,299 \\
\hline 12 & Zinc $(\mathrm{Zn})$ & $\$ /$ ton & $\begin{array}{l}0.007 x^{5}-0.5035 x^{4}+12.45 x^{3}-118.34 x^{2}+ \\
361.44 x+994.46\end{array}$ & 0.5390 & 2,297 & 2,399 & 2,632 & 3,057 & 3,747 \\
\hline 13 & Nickel (Ni) & $\$ /$ ton & $5090.4 \mathrm{e}^{0.0586 \mathrm{x}}$ & 0.5798 & 23,358 & 24,768 & 26,263 & 27,848 & 29,529 \\
\hline
\end{tabular}

Table 4. Forecast of Mineral Commodity Price Trends (Continued)

\begin{tabular}{|c|c|c|c|c|c|c|c|c|c|c|}
\hline \multirow{3}{*}{$\begin{array}{l}\mathbf{N} \\
\mathbf{O}\end{array}$} & \multirow{3}{*}{ COMMODITY } & \multirow{3}{*}{ UNIT } & \multirow{3}{*}{$\begin{array}{l}\text { FORECASTING FORMULA } \\
\text { (y) }\end{array}$} & \multirow{3}{*}{$\mathbf{R}^{2}$} & \multicolumn{6}{|l|}{ YEAR } \\
\hline & & & & & 2020 & 2021 & 2022 & 2023 & 2024 & 2025 \\
\hline & & & & & 31 & 32 & 33 & 34 & 35 & 36 \\
\hline 1 & Oil & $\$ / \mathrm{TOE}$ & $0.232 x^{2}-1.933 x+20.34$ & 0.912 & 183 & 196 & 209 & 223 & 237 & 251 \\
\hline 2 & LPG & \$/MBtu & $0.487 \mathrm{e}^{0.074 \mathrm{x}}$ & 0.746 & 5 & 5 & 6 & 6 & 6 & 7 \\
\hline 3 & LNG & \$/MBtu & $0.010 x^{2}-0.296 x+4.584$ & 0.386 & 5 & 5 & 6 & 6 & 6 & 7 \\
\hline 4 & Coal (High Rank) & $\$ /$ ton & $0.23 x^{2}-2.815 x+42.69$ & 0.63 & 176 & 188 & 200 & 213 & 226 & 239 \\
\hline 5 & Coal (Low Rank) & $\$ /$ ton & $-0.021 x^{2}+3.053 x-12.58$ & 0.742 & 62 & 64 & 65 & 67 & 69 & 70 \\
\hline 6 & Gold $(\mathrm{Au})$ & $\$ /$ tr oz & $4.627 x^{2}-71.117 x+536.86$ & 0.8929 & 2,779 & 2,999 & 3,229 & 3,468 & 3,716 & 3,973 \\
\hline 7 & Silver (Ag) & $\$ /$ tr oz & $0.0736 x^{2}-0.9446 x+6.6288$ & 0.7911 & 48 & 52 & 56 & 60 & 64 & 68 \\
\hline 8 & Aluminum (Al) & \$/ton & $1270 \mathrm{e}^{0.0222 x}$ & 0.4723 & 2,527 & 2,584 & 2,642 & 2,702 & 2,762 & 2,824 \\
\hline 9 & $\operatorname{Tin}(\mathrm{Sn})$ & $\$ /$ ton & $789.72 x+106.11$ & 0.6810 & 24,587 & 25,377 & 26,167 & 26,957 & 27,746 & 28,536 \\
\hline 10 & Lead $(\mathrm{Pb})$ & $\$ /$ ton & $5.303 x^{2}-53.67 x+654.2$ & 0.783 & 4,087 & 4,367 & 4,658 & 4,960 & 5,272 & 5,595 \\
\hline 11 & Copper $(\mathrm{Cu})$ & $\$ /$ ton & $19.224 x^{2}-220.76 x+2620.5$ & 0.7863 & 14,251 & 15,242 & 16,270 & 17,338 & 18,443 & 19,587 \\
\hline 12 & Zinc (Zn) & $\$ /$ ton & $\begin{array}{l}0.007 x^{5}-0.5035 x^{4}+12.45 x^{3}- \\
118.34 x^{2}+361.44 x+994.46\end{array}$ & 0.5390 & 4,784 & 6,265 & 8,302 & 11,020 & 14,561 & 19,081 \\
\hline 13 & Nickel (Ni) & $\$ /$ ton & $5090.4 \mathrm{e}^{0.0586 \mathrm{x}}$ & 0.5798 & 31,311 & 33,200 & 35,204 & 37,328 & 39,581 & 41,970 \\
\hline
\end{tabular}

This table shows the forecast of price trends of mineral commodity and the formula 


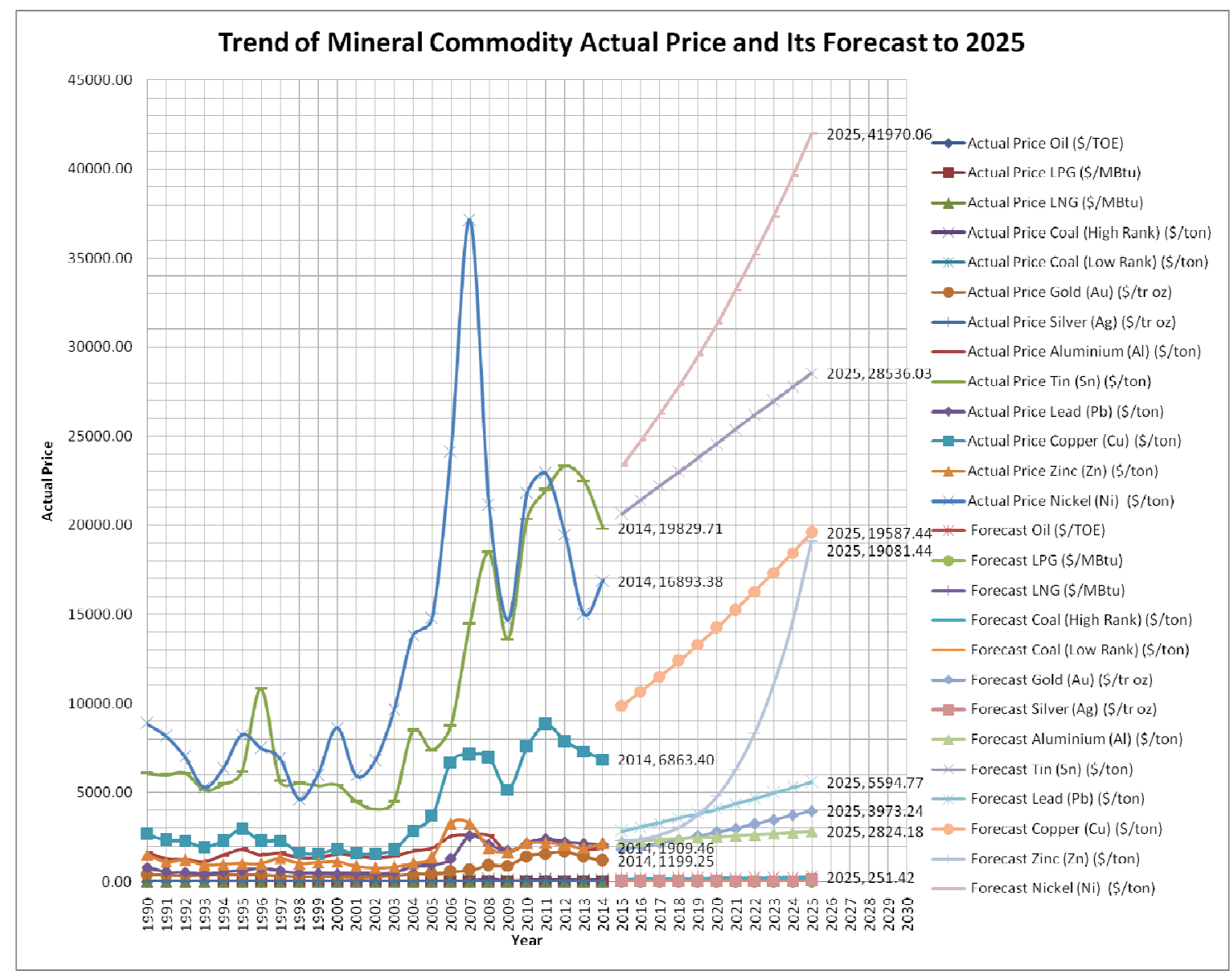

Note: $\$=$ US\$

Figure 3. Actual Price Trends of Mineral Commodity 1990-2014 and Its Forecast to 2025.

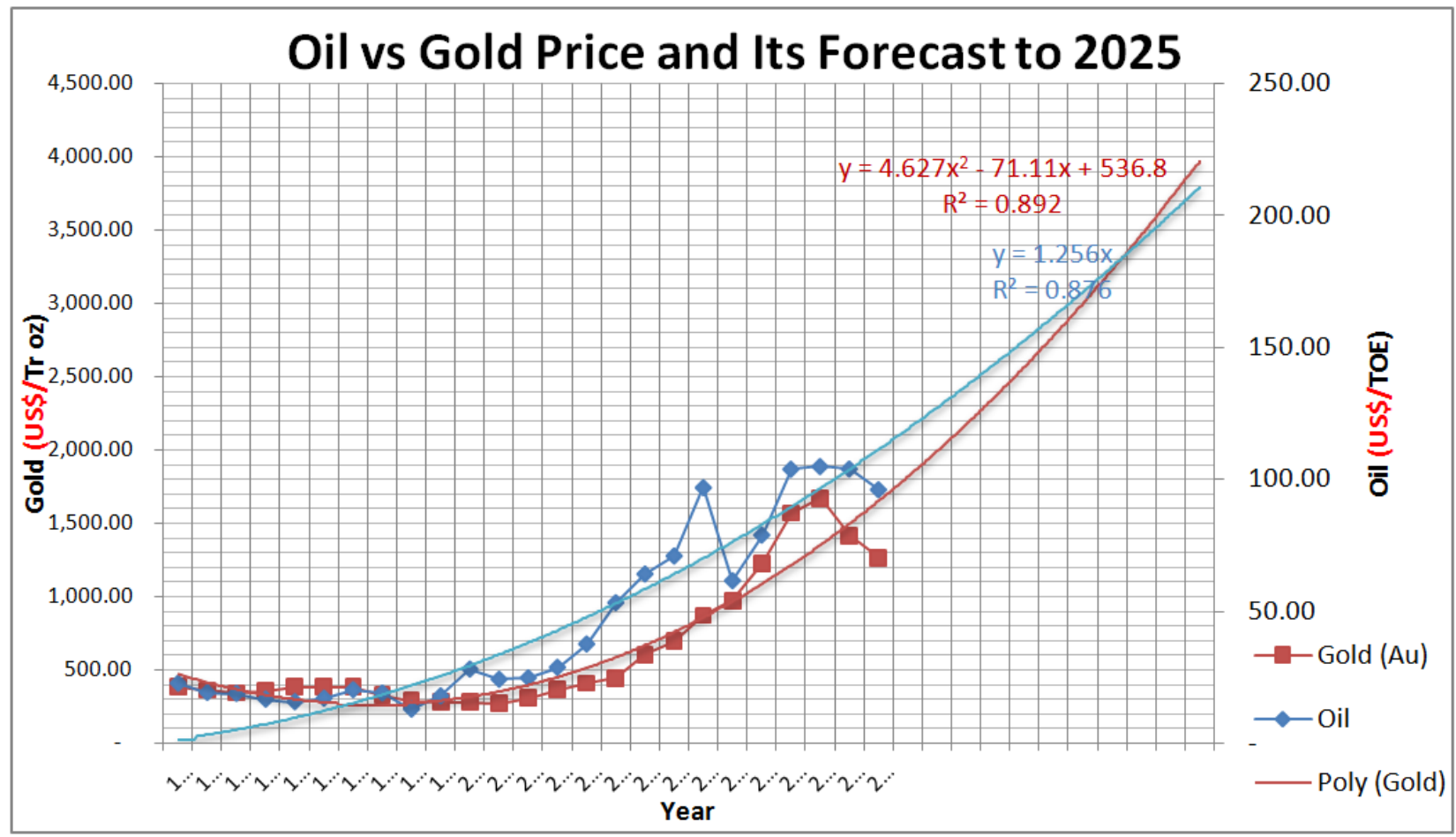

Figure 4. Oil Versus Gold Price 1990-2014 and Forecast to 2025. 


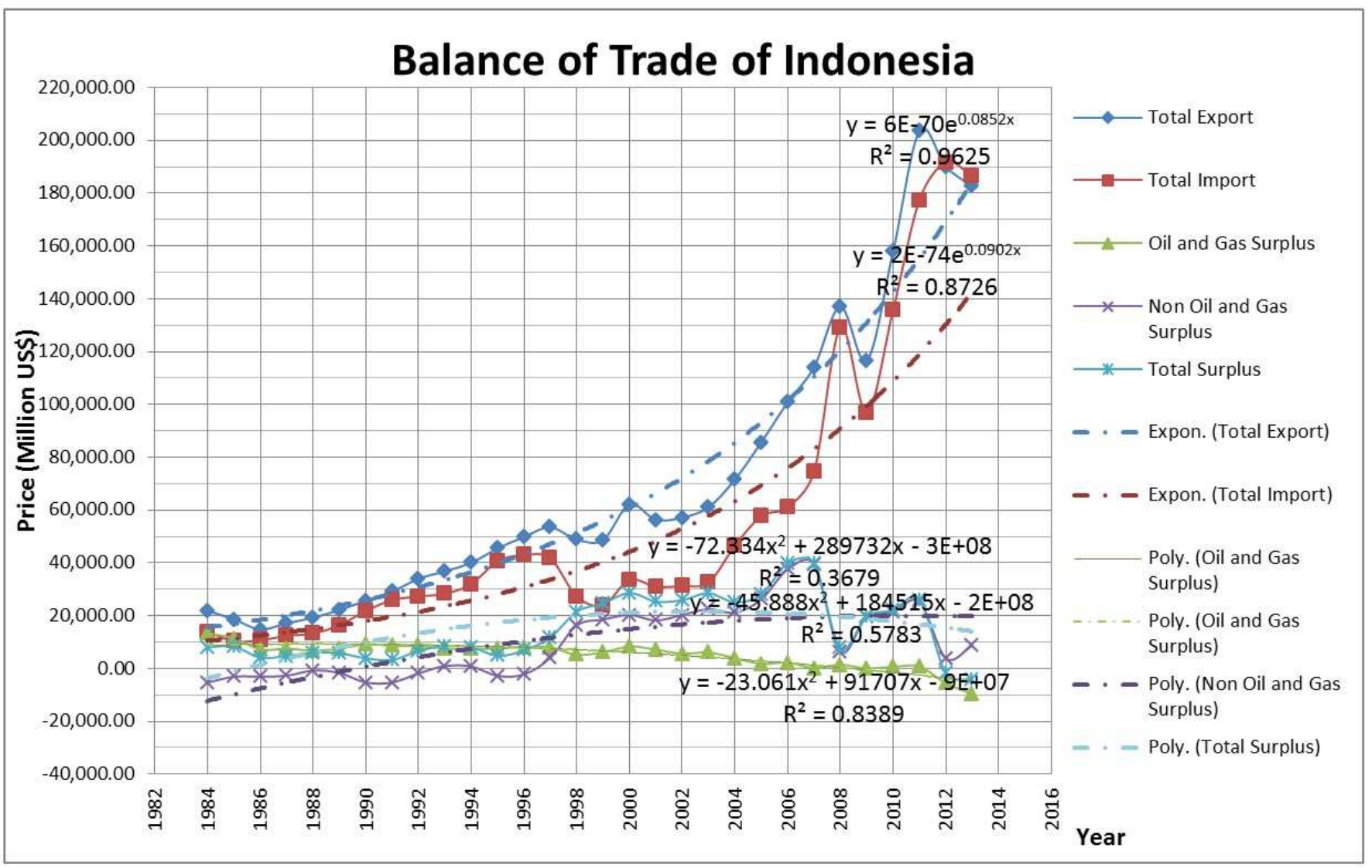

Figure 5. Indonesia Balance of Trade 1984-2014.

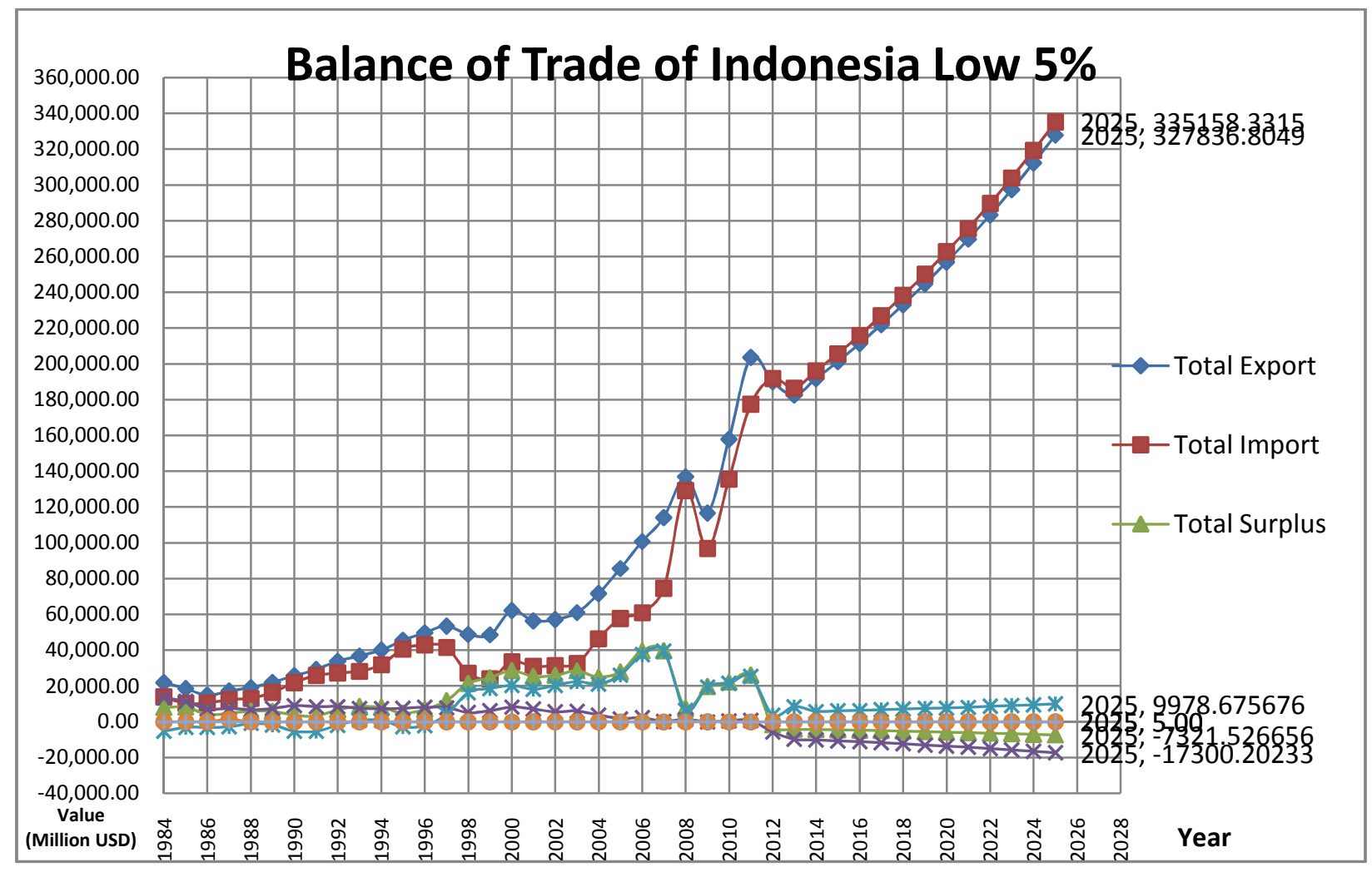

Figure 6. Indonesia Balance of Trade, Low Projection of 5\% 2015-2025. 


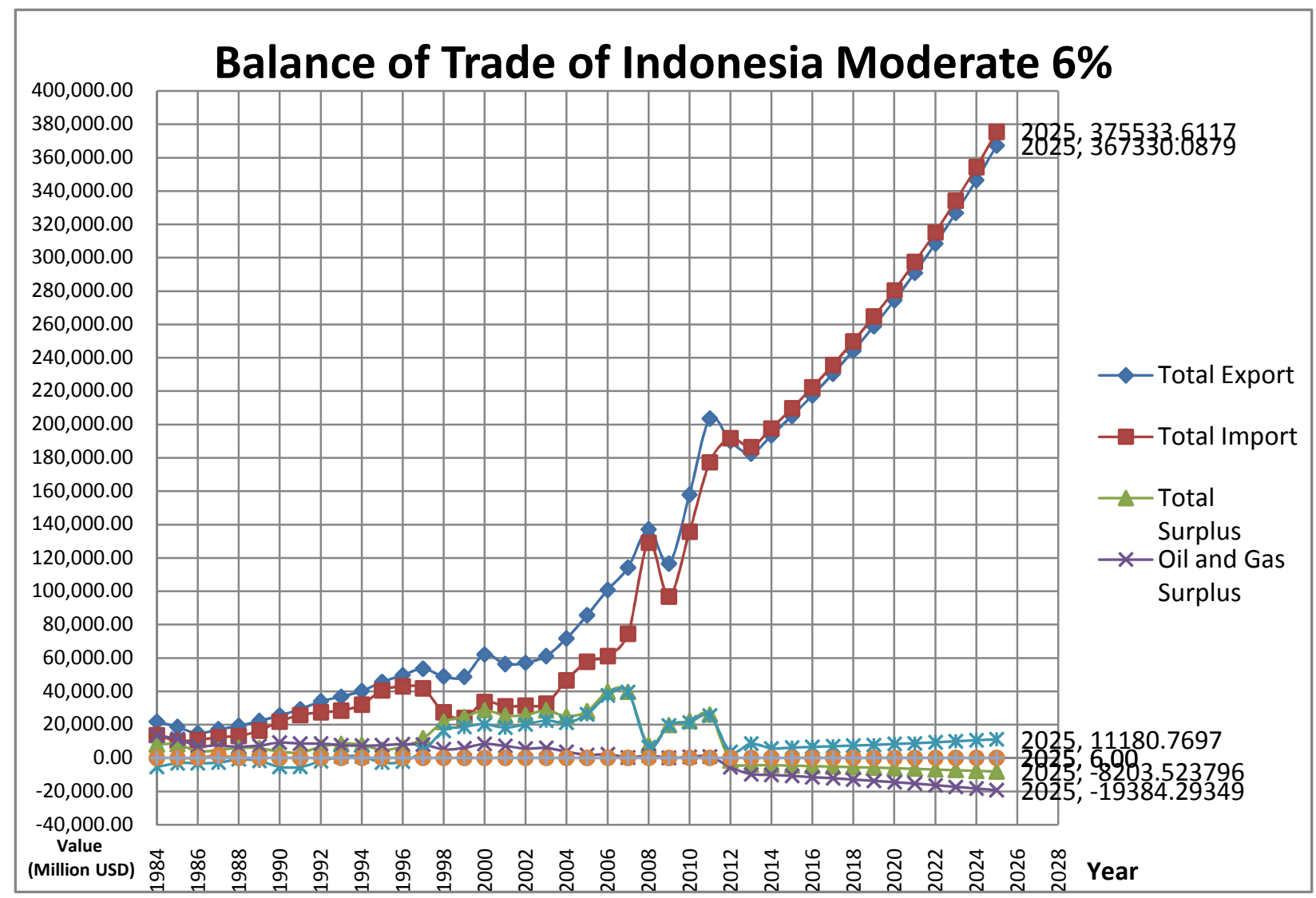

Figure 7. Indonesia Balance of Trade with moderate projection of 6\% 2015-2025.

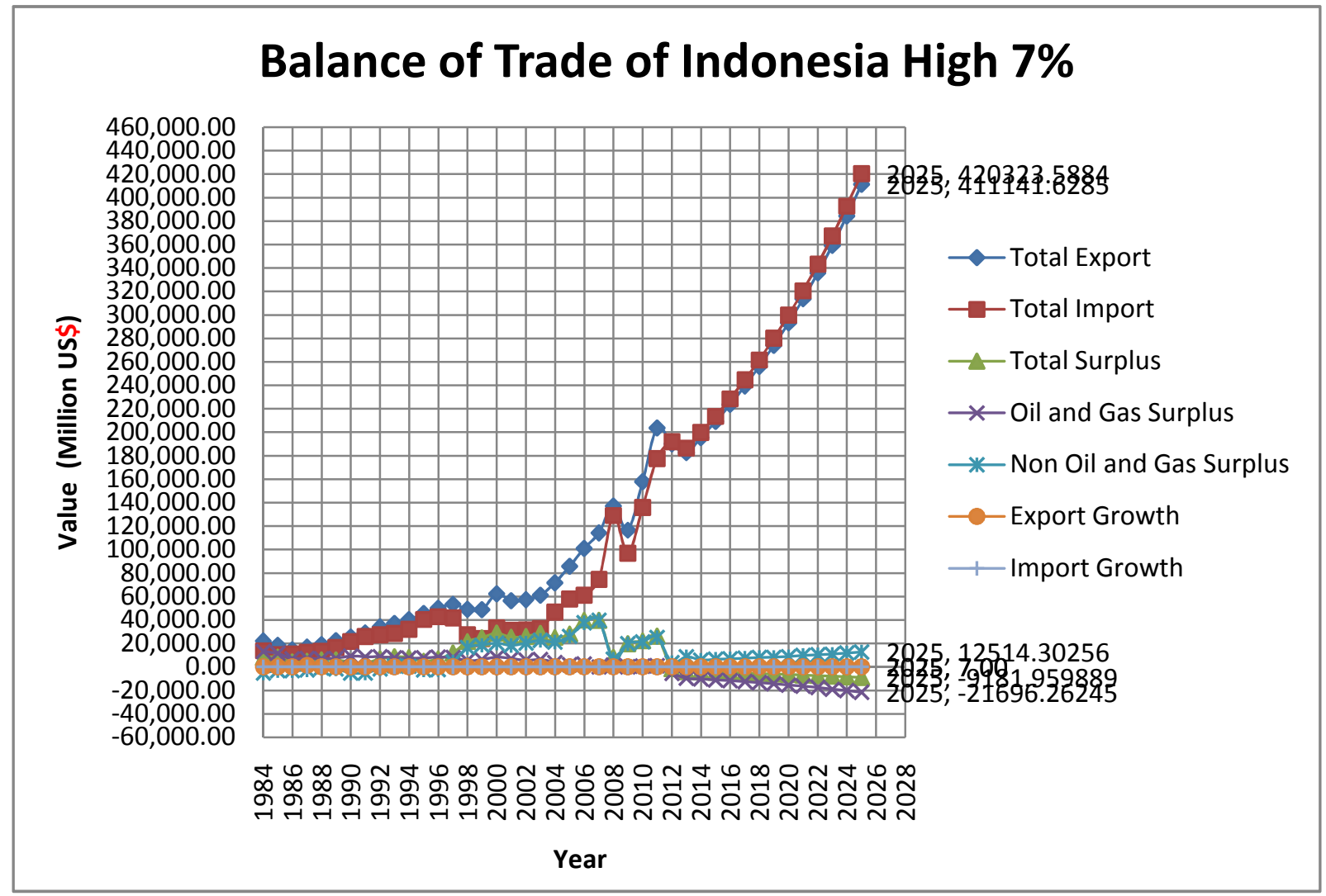

Figure 8. Indonesia Balance of Trade with high projection of 7\% 2015-2025. 


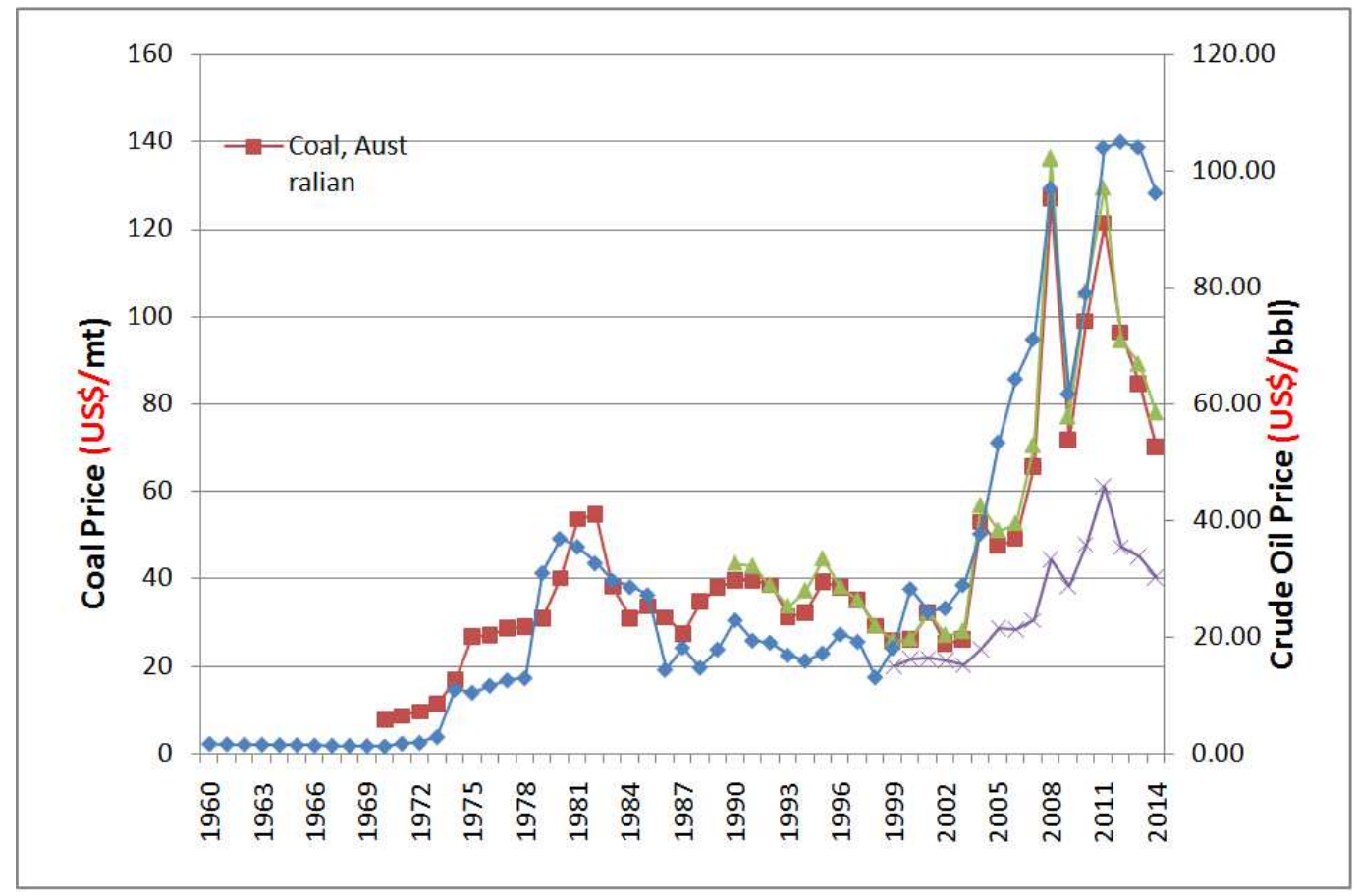

Figure 9. Price Trend of Coal and Oil.

Coal. Given the relatively large national coal reserves compared to oil and gas, coal expected to be the main source of energy Indonesia in the future. Currently coal is used as fuel power plants and other sources of energy thermal in the industry (coking coal). The future of coal beneficiation is to produce liquid coal to replace liquid fuel demand such as oil. Future coal supply will gradually replace petroleum so the percentage of coal usage is expected to increase from $20 \%$ in 2010 to $32 \%$ in 2030 . National coal demand will be met from national coal reserves which is quite large. In addition to meet domestic demand, coal production is also exported. With backup large enough, demand for coal to market in the country will be able to be supplied from production in country. Imports of coal to date very little because it is only used for special purposes. Domestic demand for coal is used for final energy in the industrial sector and primary energy to power plant. Based on Table 4 and Figure 3 it is obtained prediction of coal price in 2025 of US\$ 239.43 per ton for high rank coal and US\$ 70.11 per ton for low rank coal.

Economically, if a commodity has a function that can be substituted for each other for example oil and coal then it will easily happen displacement consumption of one type of commodity to commodity substitution in the event of a significant price increase. However, based on the energy sector commodity price curves are presented in Figure 9 it is shown that the substitution function is not normal. Some of the reasons that led to the ineffectiveness of the substitution function, is firstly because of large infestations in causing displacement consumption of energy infrastructure is rigid, Secondly, due to growth in energy demand is much greater than the growth of supply so that if there is the addition of new supply will be directly absorbed by the market. Third, the existence of a long-term contract agreement makes it difficult to transform (Soelistijo, 2011) [43]

Still from Figure 10, it can be noted that the Coal Reference Price (HBA) are set by the Ministry of Energy and Mineral Resources of the Republic of Indonesia and Coal for High Rank Coal has a pattern similar to the Australian coal prices.

Gold. Precious metal prices declined sharply during 2013. The precious metals price index of the World Bank on average 17 percent lower for the whole of 2013. The decline was marked reversal from the 11 consecutive years of rising prices of precious metals and reflect changes in global risk perceptions and inflation, given the status gold as a "safe haven" assets. Silver prices averaged 23 percent lower, while gold and platinum prices fell by 15 and 4 percent, respectively, the average for the year. Based on Table 4 and Figure 4 it is obtained prediction of gold price in 2025 of US\$ 3973.93 per tr.oz.

Gold and oil are two commodities which in nature is not directly related to its use as well as the group of other commodities mentioned earlier, are not mutually complementary and not as well as the same input in a particular industry. But the behavior of oil and gold price movements are generally moving in the direction of the pattern seems to be interconnected. In addition to the direction, from the curves presented in Figures 3and 4 also seen other behaviors that there are certain periods in which the gold price moves up and down oil prices that occurred in 1985-1986, and also reverse the pattern of the gold price moves down while the rise in oil prices that occurred in 1998-2000 the current economic crisis at East Asia and Southeast Asia regions.

Gold is believed to choose a value that is never eroded by inflation caused gold to get a special place in world trade and investment is a hedge, uniformity This perception led to the value of gold will continue to firm in the long run. In the 
hedging function and belief in the value of gold that will never go down in the long run, countries rich in oil-producing excess profits from the sales and rise in oil prices to increase their gold reserves boosting demand and led to the gold price appreciation itself. Conversely, when the price of oil downs, gold reserves will be released into the market so that the excess supply and the price of gold fell. This behavior was also performed by the business to protect their assets from inflation scour and of the risk of loss for example due to rising production costs due to higher oil price. Both of these acts may explain why the price of gold and oil prices have a general pattern of movement in the same direction.

For the special case that occurred in 1998-2000 in which the gold price moves down while the rise in oil prices caused by the amount of gold supply comes from the release of gold reserves by countries hit by the current economic crisis, especially countries of East and Southeast Asia and funds raised be used in their efforts to emerge from the crisis by encouraging investment and industrialization role in their country, further these efforts to encourage an increase in demand for the oil industry needs. While beyond the year of 2020 the projected increasing price of gold would be more stronger than oil one (Figure 4).

Silver. Silver is second precious metal after gold, which since the first traded as a commodity mineral. As the development of jewelry, the soaring price of silver technological advances coupled substitution of silver by various other materials to make use of silver be reduced, but silver remains a precious metal commodity, whose value is timeless as well as gold, and its main use remains dominate jewelry, arts and crafts .Based on Table 4 and Figure 4 obtained prediction of silver price in 2025 of US\$ 68,01 per tr.oz. (Figure 3).

Aluminum. On an international scale, Indonesia is the largest bauxite producer 7 th in the world. From the price, the price of bauxite is determined by the International market. Several factors affect the price is the dominant development of alumina and aluminum smelting plant. In the last 10 years, the price of bauxite almost 2-fold to fold, which was originally only US\$17/MT to about US\$26/MT, or grow an average of $5.19 \%$ per year, while the price of aluminum folding 2.5 times, i.e. the original US\$1468/MT increased to US\$3620/MT, or grew at an average of $11.24 \%$ per year. Based on Table 4 and Figure 3 obtained prediction of Aluminum price in 2025 of US\$ 2824.28 per ton (Figure 3).

Tin. Indonesia is a major producer of tin world, in addition to Bolivia as the largest producers. Tin is needed as the backbone of other industries as well as synonymous with war industry (bullets), the needs of the world's tin is increasing year-on-year rises in the cost significantly, especially since 2006 up to 2012. Indonesia has imposed a tin commodity trading conditions in the country through the Indonesia Tin stock, this step is believed to foster confidence in the market Indonesian tin. Based on Table 4 and Figure 3 obtained prediction of tin price in 2025 of US\$28,536 per ton.

Copper. Indonesia is ranked 20th in the world based on the location of the mine and copper production capacity. PT
Freeport Indonesia was ranked third, while the PT Newmont Nusa Tenggara is the eleventh position. Ranked first and the second is the state mining company in Chile. Especially copper needs of the cable industry, and other electrical equipment. Although the price of copper world possessed a tendency to fluctuate, but the trend in the last 10 years shows an increase of more than $200 \%$, it is possible also occur in the future in line with the needs of the growing copper. Based on Table 4 and Figure 4 obtained prediction of zinc price in 2025 of US\$ 19,587 per ton (Figure 3).

Zinc. The estimate says that globally, zinc mine production is expected to rise by 2.6 percent this year to 13.57 tons as output from China, followed by Australia, it will increase. Production by other Asian countries such as South Korea, currently the world's third largest producer of lead behind China and the United States, and India and Kazakhstan are also expected to increase. Based on Table 4 and Figure 4 obtained prediction of zinc price in 2025 of US\$ 19,081 per ton (Figure 3).

Nickel. Indonesian nickel production, both nickel ore, nickel or nickel rough, almost entirely used to meet export requirements. So the Indonesian nickel demand is determined by the world nickel demand. In the global market, the demand for nickel is expected to increase by $3 \%$ per year, so that by 2015 demand for nickel metal was estimated at 2,000,000 tons. Largest consumer of nickel in the world today is the Asian countries (especially China), which in 2009 accounted for $61 \%$ of world nickel consumption, followed by Europe $26 \%$, America 10\%, Africa and Oceania only 3\% .Meanwhile, the needs of the world's nickel supplied by 20 companies including the company of Indonesia, which was recorded with a production rate of approximately 1,329 million tons of nickel. Indonesian nickel production, either nickel, ferronickel or nickel rough, almost entirely used to meet export requirements. So the demand for nickel Indonesia is determined by the world nickel demand. In the global market, the demand for nickel is expected to increase by $3 \%$ per year, so that by the year 2015 nickel metal demand is estimated at 2,000,000 tons. Largest consumer of nickel in the world today is the Asian countries (especially China), which in 2009 accounted for $61 \%$ of world nickel consumption, followed by Europe 26\%, America 10\%, Africa and Oceania only 3\% .Meanwhile, the needs of the world's nickel supplied by 20 companies including the company of Indonesia, which was recorded with a production rate of approximately 1,329 million tons of nickel Based on Table 4 and Figure 3 obtained prediction of zinc price in 2025 of US\$ 41,970 per ton.

Mining sector is one of the mainstays of Indonesia in achieving the goal of economic development is believed to be able to support Indonesia in its transformation towards developed countries. Exploitation of natural resources continue to be made during the $30 \mathrm{~s}$ decade considered not provide sufficient results in achieving the ideals of the nation. This prompted the government to find a new formula in the use and management of natural resources in order to provide higher economic impact.

The declining contribution of the mining sector in the 
Indonesian economy, especially in the oil and gas subsector as shown in Figure 2, Indonesia decided to encouraging or increase the value of the benefits of mineral and coal mining subsector by issuing a law No. 4 of 2009. Various arguments and reasons about the importance of these laws has been expressed by the observer. But in this paper presenting it in a different form that is based on the graphs presented in Figures 2and 10, it is shown that the sectors of mining and quarrying of minerals and coal are still able to maintain it contribution on GDP nominal value even showed an increase.

Based on Figure 3, during the year 2000 to 2014 the contribution of the mining sector in general experienced a decreasing trend, but the decline was caused by a decline in oil and gas subsector as a result of declining productivity of domestic oil wells. While the excavation subsector showed an increase although the increase is relatively small. In the mineral and coal mining subsector, which are periodic fluctuations that in 2000-2002 showed an increase, 2003-2004 corrected, nail again in 2005-2006 and again corrected in 2007-2008 and then again showed improvement in 2009 -2010 and thereafter moved almost constant.

Nominally, the value of the general mining sector throughout 2000 through 2014 has increased. Thus the decrease in contributions was due to the increase in GDP growth outpacing the growth of the mining and quarrying sector. Nominal value of oil and gas subsector be offset by an increase in the nominal value of the mining subsector (Figure 2).

Publication of laws prohibiting new mining exports as raw materials to encourage efforts downstream mineral and coal mining materials. Based on Figures 2 and 10 it is shown that prior to the issuance of the law downstream sector contribution of mining to GDP showed a decreasing trend. With the presence of the laws of mineral and coal in 2009 can make downstream sector of mining and quarrying of minerals and coal back excited and managed to maintain contribution to GDP besides its role in ding regional development such as physical (infrastructure, physical environment and spatial order) as well as non-physical development (corporate social responsibility including community development). Currently, net social gain created by the mining regional development amounted to $1-20 \%$ of its revenue devoted to the local community development (Soelistijo, 2013, [38,39].

In Figures 2 and 10, it is shown that in nominal terms, the value of the downstream oil and gas has decreased from year to year, besides in term of percentage. The decline in the nominal value of the downstream oil and gas follows the downward trend of the upstream sector as shown in Figure 2.The nominal value of the general mining increased and able to offset a decline in the nominal value of oil and gas. This is a positive value of the presence of the law on mineral and coal.

The declining BOT/GDP ratio within the years of 20002014 was of $9.23 \%$ as the annual average, from $20.6 \%$ in 2000 down to $3.51 \%$ in 2011. Then in 2012 the BOT/GDP ratio became negative with the annual ratio of $-0.19 \%$ in 2014 and $0.45 \%$ in 2013 or with the average annual ratio of $-0.3 \%$ within 2011-2014 (Table 5). This negative BOT means that Indonesia suffered from the excess imports mainly of the consumptive materials greater than that of the capital goods and raw materials. Then it is necessary to have firm effort of how to push the export through releasing incentives to the potential exporting sectors at least at the average BOT/GDP ratio of $7.89 \%$, and not just based on business as usual.

It could be noted that the GDP growth rate was declining since 2010 and on from around $6-7 \%$ down to $5 \%$ or less in the first quarter of 2015 of $4.7 \%$. It is expected that by the firm pushing power launched by the GOI since the new government started at the end of 2014 by inviting foreign investors based on the new policy of incentives with all facilities among others of shortening the permit time process and the spirit and program of infrastructural development in the country relied on the realization of concept of maritime highway development because Indonesia is an archipelago, then the growth rate of GDP would be increasing in 2015 and on.

One of among the many policies is how to push export of the potential exporting sectors such as general mining, creative industry, fishery, and other manufacturing industry to revitalize BOT becoming positive.

Table 5. Indonesia current value of GDP, BOT and BOT/GDP ratio, 2000-2014.

\begin{tabular}{|c|c|c|c|c|c|}
\hline Year & GDP(IDR Trillion) & BOT(IDR Trillion) & BOT/GDP ratio (\%) & Average ratio(\%) & \\
\hline 2014 & 10094.9 & -18.86 & -0.19 & ] & \} \\
\hline 2013 & 9007.3 & -40.76 & -0.45 & ]- 0.28 & \} \\
\hline 2012 & 8230.9 & -16.69 & -0.20 & ] & \} \\
\hline 2011 & 7419.2 & 260.61 & 3.51 & & \} \\
\hline 2010 & 6446.9 & 221.15 & 3.43 & ) & \} \\
\hline 2009 & 5606.3 & 191.81 & 3.42 & ) & \} \\
\hline 2008 & 4948.7 & 78.23 & 1.59 & ) & \} \\
\hline 2006 & 3339.2 & 397.33 & 11.90 & ) & $7,89 \%$ \\
\hline 2005 & 2774.3 & 279.59 & 10.08 & 9.23 & \} \\
\hline 2004 & 2295.8 & 250.60 & 10.92 & ) & \} \\
\hline 2003 & 2013.7 & 285.08 & 14.16 & ) & \} \\
\hline 2002 & 1821.8 & 258.70 & 14.20 & ) & \} \\
\hline 2001 & 1646.3 & 253.59 & 15.40 & ) & \} \\
\hline 2000 & 1389.8 & 286.09 & 20.58 & ) & $\begin{array}{l}\} \\
\}\end{array}$ \\
\hline
\end{tabular}

Source: Badan Pusat Statistik, 2015, [15], Recalculated. 


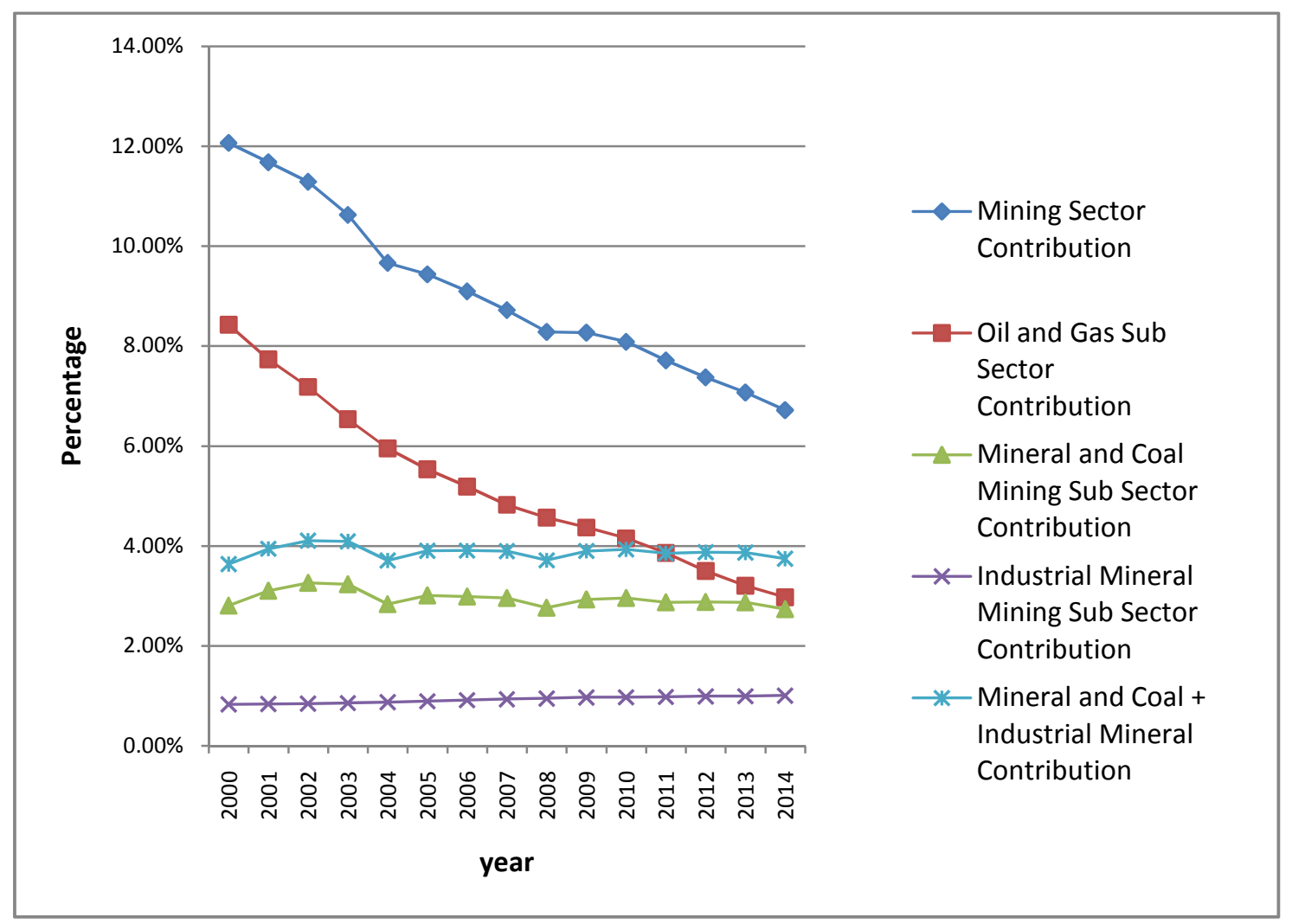

Figure 10. Mining Sector Contribution for Indonesian GDP (by percentage).

Following the program of GDP projection with low of $5 \%$, moderate (middle) $6 \%$ and high of $7 \%$, and if it is assumed that BOT has the same rate of projection then BOT would be positive if it is projected by using $7 \%$ or higher $(7.9 \%)$ following the GDP projection based on the investment program and not only heavily based on the consumption as before the year of 2015 (Figures6,7 and 8). To recover the declining of the mining sector contribution to the GDP (Figures10) since 2000, then the government regulation on added value of the mining sector was released in 2014 to prohibit the export of mineral as raw materials and it should be processed domestically toward supplying energy and semi finished product for domestic downstream industries in the purpose of producing end use commodity containing as high as possible added value.

\section{Conclusions and Recommendations}

The increasing trend of several important mineral commodity price since 2000 is caused by increasing demand because of three factors those are fast macroeconomic growth in OECD countries, giant demand from China and speculative activity due to negative stock market. However, sometimes decreasing because of world crisis, scarcity, and other problems in the world related to mining, trade, and relationship between countries, such as fundamental matter, including long-run demand growth, technical change that opens up new sources of supply, changes that transform the operation of financial markets, and macro-economic shocks, etc.
Mining sector contributes about $6-12 \%$ of Indonesian Gross Domestic Product and increasing from time to time besides doing regional development program. Contribution of mining sector includes trade of mineral commodity, regional development by companies, etc. It is shown that mining takes an important role in the Indonesian economy. The percentage contribution to GDP Indonesian oil and gas sector declined since in 2002 from the previous year amounted to $7.4 \%$ with a value of IDR $111,450.9$ Billion to IDR $86,477.6$ billion in 2014 by the percentage of $2.97 \%$. Metallic mineral and coal mining sector contribution keeps increasing since the year of 2000 and reach IDR 79620.1 billion in 2014. This is due to the declining oil and gas lifting and mineral commodity's price hikes due enormous demand from industrialized countries.

Forecasting prices in 2025, all commodity prices are predicted to rise namely petroleum commodities (US\$251.42/TOE), gold (US\$ 3973.93/troy ounce), LPG (US 6.9/MBtu, LNG (US\$ 6.8 /MBtu), high rank coal (US\$ 239.43/ton), low rank coal (US\$ 70.11/ton), silver (US\$ 68.01/troy ounce), aluminum (US\$ 2,824.23/ton), tin (US\$ 28.536/ton), lead (US\$ 4,927.81/ton), zinc (US\$ 2,933.26/ton), copper (US\$ 12,341.88/ton), nickel (US\$ 41,970/ton), platinum (US\$ 4,162.35/troy ounce), iron ore (US\$ 247.26/ton). The present declining BOT has been counter-acted by new mineral added value policy. This increasing trend of mineral commodity price but followed by the declining even negative BOT might be followed by the increasing BOT due to the new government policy of pushing its mineral intensive consuming downstream 
industries respectively and asa whole within the coming years.

The forecast of mineral commodity should be done by another improved methods and models so that it could be compared from one to the others. The parameters which affect price trends and forecast should be completed before forecasting, so that the result will be more precise and accurate.

\section{References}

[1] Anonymous (a), 2012, Harga Batubara Acuan (HBA) \& Harga Patokan Batubara (HPB), http://www.djmbp.esdm.go.id/sijh/HBA $20 \quad$ February 202013.pdf, accessed on 1 April 2013.

[2] Anonymous (b), 2012, Non Ferrous Metals-Historical Data, http://www.lme.com/metals/non-ferrous/historical_data, accessed on 15 February 2013.

[3] Anonymous (c), 2013, Gold-London Price Market Fix, http://www.kitco.com/scripts/hist_charts/yearly_graphs.plx, accessed on 15 February 2013

[4] Anonymous (d), 2015, OPEC Basket Price, http://www.opec.org/opec_web/en/data_graphs/40.htm, accessed on 10 February 2015.

[5] Anonymous (e), 2013, Silver-London Price Market Fix, http://www.kitco.com/scripts/hist_charts/yearly_graphs.plx, accessed on 15 February 2013.

[6] Anonymous (f), 2015, Gold and Silver-London Price Market Fix,

http://www.kitco.com/scripts/hist_charts/yearly_graphs.plx, accessed on 10 February 2015

[7] Anonymous (g), 2015, Tin LME spot price chart, http://ycharts.com/indicators/tin_lme_spot_price, accessed on 10 February 2015.

[8] Anonymous (h), 2015, Lead LME spot price chart, http://ycharts.com/indicators/lead_lme_spot_price, accessed on 10 February 2015.

[9] Anonymous (i), 2015, Copper LME spot price chart, http://ycharts.com/indicators/copper_lme_spot_price, accessed on 10 February 2015.

[10] Anonymous (j), 2015, Nickel LME spot price chart, http://ycharts.com/indicators/nickel_lme_spot_price, accessed on 10 February 2015.

[11] Anonymous (k), 2015, Harga Batubara Acuan (HBA) Desember http://www.minerba.esdm.go.id/library/content/file/28935HBA $20 \quad$ Desember 202014/8a8be52ae7f658b5a18b47b21c6e4e4b2014-12-09-0038-04.pdf, accessed on 10 February 2015.

[12] Anonymous (1), 2015, zinc LME settlement price chart, http://ycharts.com/indicators/zinc_lme_settlement_price, accessed on 10 February 2015.

[13] http://en.wikipedia.org/wiki/Ring_of_Fire accessed on 25 March 2015

[14] http://wikipedia.org
[15] Badan Pusat Statistik. Statistik Indonesia 2014. 2015, Jakartahttp://www.bps.go.id/pdb.php

[16] http://www.lme.com/en-gb/metals/

[17] http://moharifwidarto.wordpress.com $/ 2008 / 10 / 25 / \mathrm{krisis}-$ keuangan-global-2008-beda-dengan-krisis-keuangan-1997/

[18] http://bps.go.id/data

[19] Cuddington, J. T, D. Jerrett. "Super Cycles in Metals Prices?" IMF Staff Papers 55, 4(December), 541-565, 2008.

[20] Editorial. Understanding international commodity price fluctuations. Journal of International Money andFinance 42. 2014.

[21] Gujarati, DN. Fundamental econometrics. Penerbit Erlangga, Jakarta, 2006.

[22] Gujarati, DN. and Porter, DC. Basic Econometrics 5 th Edition. New York: McGraw-Hill, 2009.

[23] Jacks, D., K. O'Rourke, J. Williamson. Commodity price volatility and world market integration since 1700 . The Review of Economics and Statistics, 93(3):800\{813\}, 2011.

[24] Labys, WC. Dynamic commodity models: Specification, estimation, and simulation. Lexington Books, D,C. Heath and Company, Lexington, 1973.

[25] Li, Y., C. Wu, J. Liu, P. Luo. A Combination Prediction Model of Stock Composite Index Based on Artificial Intellegent Methods and Multi-Agent Simulation. International Journal of Computational Intelligence Systems, 7(5), 853-864, 2014. http://dx.doi.org

[26] Maddala, GS. Econometrics. McGraw-Hill Book Company, New York, 1977.

[27] Radetzki, The anatomy of three commodity booms, Resources Policy 31, 2006, pg. 56-64

[28] Radetzki, Eggert, Lagos, Lima and Tilton. The boom in mineral markets: How long might it last?, Resources Policy 33, 2008, pg. 125-128.

[29] Schaeffer, PV, 2008. Commodity modeling and prices: Methods for analyzing resourcemarekt behavior. John Wiley \& Sons, Inc, Canada.

[30] Soelistijo UW, T. Suseno, I. Suherman, Mujib, C. Nas. Ekonomi Regional dan Model Penerapannya: Pengembangan Sumber Daya Mineral dan Energi Dalam Rangka Otonomi Daerah di Indonesia.Pusat Penelitian dan Pengembangan Teknologi Mineraldan Batubara, Departemen Energi dan Sum,ber Daya Mineral, 2003.

[31] Soelistijo, UW. Prospect of Potential Nickel Added Value Development in Indonesia.Earth Science. Science Publishing Group, USA.Vol. 2, No. 6, 2013, pp. 129-138. doi: 10.11648/j.earth.20130206.13, 2013.

[32] Soelistijo, UW. The Influence of Geopolitics and Strategical Factors upon the Development of Natural and Human Resources in Indonesia. Social Sciences. Science Publishing Group, USA. Vol. 2, No. 6, 2013, pp. 200-211. doi: 10.11648/j.ss.20130206.15, 2013.

[33] Soelistijo, UW. Control of Illegal Mining (PETI) in Indonesia: Policy and Program.Indonesian Mining Journal, ISSN 08549931, Volume 14 Number 1, February 2011, R\&D Centre for Mineral and Coal Technology, tekMIRA), 2011. 
[34] Soelistijo, UW. Several evaluation and analytical indicators of regional autonomy implementation impacts in Indonesia: Energy and Mineral Resource Sector Development.Indonesian Mining Journal, ISSN 0854-9931, Volume 15 Number 2, June 2012, R\&D Centre for Mineral and Coal Technology, tekMIRA), 2012.

[35] Soelistijo, UW. Beberapa Indikator Nilai Tambah Ekonomi Indonesia: Sektor Energi dan Sumber DayaMineral (Several Indicators of the Indonesia Economy Added Value: Energy and Mineral Resource Sector). Jurnal Teknologi Mineral dan Batubara, ISSN 1979-6560, Vol. 9 No. 1, January 2013, Puslitbang Teknologi Mineral dan Batubara), 2013.

[36] Soelistijo, UW, B. Santoso. A Brief Overview of The Scarcity of The Indonesia Gold Mining,Buletin Tekmira, ISSN 08547890, Nomor 28, Tahun 11, Bandung, Mei, 2003.

[37] Soelistijo, UW. Economic Evaluation of the Existing and Potential Indonesian Coal Utilization.EarthScience.Vol. 2, No. 6, 2013, pp. 120-128. doi:10.11648/j.earth.20130206.12

[38] Soelistijo, UW. Political Economy of Resources and Its Development: The Case of Indonesia.American Journal of Business,Economics and Management. Vol. 1, No. 1, 2013, pp. 16-24.

[39] Soelistijo, UW. The Influence of Geopolitics and Strategical Factors upon the Development of Natural and Human Resources in Indonesia. Social Sciences. Vol. 2, No. 6, 2013, pp. 200-211. doi: $10.11648 /$ j.ss.20130206.15
[40] Soelistijo, UW, B.Santoso, T. Suseno. An Eye-Bird View of Facing Scarcity of Gold Mining inIndonesia. Scientia Research Library ISSN 2348-0416 USA CODEN: JASRHB Journal of Applied Science And Research, 2014, 2 (1):11.(http://www.scientiaresearchlibrary.com/arhcive.php)

[41] Soelistijo, UW, L.O. Aswandi, 2014. "Future Trend of Mineral Industries Development in Indonesia." Earth Science. Vol. 3, No. 2, 2014, pp. 58-67. doi: 10.11648/j.earth.20140302.14, 2014.

[42] Soelistijo, UW. "Dinamika Penanaman Modal Asing (PMA) Bidang Pertambangan Umum di Indonesia",Mimbar, Jurnal Sosial dan Pembangunan, Volume XXVII, No.1 (Juni 20111), Unisba, 2011

[43] Soelistijo, UW. Laporan Perjalanan Mengikuti International Conference on Air Quality VIII, 24-27 Oktober 2011, Crystal Gateway Marriott, Arlington, Virginia, Amerika Serikat. Laporan dinas kepada Kementerian Keuangan,Rektor Unisba, dan Kapuslitbang Mineral dan Batubara, 2011.

[44] Stuermer, M. 150 Years of Boom and Bust: What Drives Mineral Commodity Prices?. Department of Economics, University of Bonn, Germany, 2013.

[45] Todaro, MP, SC Smith, 2011. Economic development. Penerbit Erlangga, Jakarta.

[46] World Bank. Commodity Market Outlook - January 2015 Edition Quarterly Report. World Bank Group, 2015. 